\title{
Notes
}

\section{Section 1981 and Private Groups: The Right to Discriminate Versus Freedom from Discrimination}

In 1968, Jones $v$. Alfred $H$. Mayer Co. ${ }^{1}$ revitalized the Civil Rights Act of $1866^{\circ}$ as an instrument with which to attack racial discrimination by private clubs and private schools. Jones consequently reawakened the conflict between freedom of association, which many have believed gives private groups a right to discriminate, and freedom from racial discrimination, guaranteed by the principles of equality undergirding the Thirteenth and Fourteenth Amendments. ${ }^{3}$

Existing legal doctrine, this Note will argue, provides no clear solution to the conflict presented; the courts will be forced to develop new doctrine which balances the interests of private groups that wish to discriminate and individuals who wish to be free from discrimination. This Note will examine alternative policies toward the conflict and their likely impact on the opposing interests. It will emphasize a range of alternatives short of a complete exemption from the 1866 Act for private groups which would nevertheless preserve a meaningful degree of freedom to choose social intimates.

1. 392 U.S. 409 (1968).

2. Now codified as 42 U.S.C. $\$ \$ 1981,1982(1970)$.

3 . Commentators first noticed the conflict created by applying $\$ 1981$ to private groups shortly after Jones. See, e.g., Larson, The New Law of Race Relations, 1969 WIs. L. REv. 470, 501-03. Commentary since then has generally pointed out the conflict and offered an opinion that it should or will be resolved against the interests of all or many private groups. See Note, Federal Power to Regulate Private Discrimination: The Revival of the Enforccment Clauses of the Reconstruction Era Amendments, 74 Colum. L. Rev. 449, 523 (1974); Note, Desegregation of Private Schools: Section 1981 as an Alternative to State Action, 62 Gro. L.J. 1363, 1396, 1400 (1974); Note, Association, Privacy and the Private Club: The Constitutional Conflict, 5 Hakv. Civ. Rights-Civ. LiB. L. REv. 460, 470 (1970); Note, The Desegregation of Private Schools: Is Section 1981 the Answer?, 48 N.Y.U.L. Rev. 1147, 1171-72 (1973); Note, Constitutional Law-Private Club Discrimination, 1970 WIS. L. Rev. 595, 600-02.

A more thorough treatment of the problem is needed at this time for two reasons. First, discrimination by private clubs and private schools is coming under increasing attack, making the time for resolution of the problem by the courts imminent. Second, several important jurists have expressed a great regard for private group rights. See pp. $1456-57 \&$ note 77 infra. Since many other judges may share these views, the creation of an cxemption from $\$ 1981$ for bona fide private groups is a clear possibility. This Note will suggest alternative solutions which might sufficiently preserve group rights without granting a complete exemption from $\$ 1981$. 


\section{The Limits of Recent Federal Civil Rights Legislation}

Two significant institutions left untouched by the federal ${ }^{4}$ civil rights legislation of the $1960^{\prime} \mathrm{s}^{\overline{ }}$ were private schools and private clubs. ${ }^{6}$ Because these institutions were excluded from the coverage of the legislation, a substantial amount of private discrimination has continued.

\section{A. The Private Club Exemption}

A primary force behind the passage of the 1964 Civil Rights Act was the need for antidiscrimination legislation covering public accommodations. ${ }^{7}$ The public accommodations title exempted from its coverage "private club[s and] other establishment[s] not in fact open to the public."

4. Several states have had civil rights statutes for a number of years. But due to the absence of legislation in many states and a disappointing record of enforcement, the most effective remedies for private discrimination have resulted from the federal statutes. See Caldwell, State Public Accommodations Laws, Fundamental Liberties and Enforcement Programs, 40 W ASH. L. REv. 841 (1965).

5. The major pieces of legislation were the Civil Rights Act of 1964, Pub. L. No. 88-352, 78 Stat. 243; and the Fair Housing Act of 1968, Pub. L. No. 90-284, 82 Stat. 81. Public accommodations were dealt with in Title II of the 1964 Act (codified at 42 U.S.C. $\$ 2000$ a (1970)). Employment discrimination was treated in Title VII of that Act (codified at 42 U.S.C. $\$ 2000 \mathrm{e}(1970)$ ). The housing discrimination provisions are codified at 42 U.S.C. $\$ \$ 3601-31(1970)$.

6. The legislation also left a number of other, less significant gaps. The public accommodations provisions do not reach small bars not selling food; nor do they reach grocery stores and department stores not selling food for consumption on the premises, retail shops, and services such as those of doctors, dentists and skilled tradesmen. Larson, supra note 3 , at $475-76$.

The public accommodations and housing statutes exempt "Mrs. Murphy's Boardinghouse"-lodging with less than five units and occupied by the owner. See 42 U.S.C. S: 2000a(b)(1), 3603(b)(2) (1970). The housing statute allows private clubs and religious organizations to give preference to members. See 42 U.S.C. $\$ 3607$ (1970). The employment discrimination statute exempts firms having under 15 employees and private clubs. See 42 U.S.C. $\$ 2000 \mathrm{e}(\mathrm{b})(1970)$. To some extent the application of the 1866 Civil Rights Act in these contexts creates the same sort of problems discussed in this Note.

7. Sit-in demonstrations had become widespread by the spring of 1963 . A series of sit-in cases had reached the Supreme Court beginning in 1960, with counsel for the demonstrators arguing for an extension of the doctrine of Shelley v. Kraemer, 334 U.S. 1 (1948), to nullify state criminal trespass law enforcement when triggered by private racial prejudice, thus raising the prospect of violent self-help in the absence of new lcgislation. See Silard, A Constitutional Forecast: Demise of the "State Action" Limit on the Equal Protection Guarantee, 66 Colum. L. REv. 855, 859-67 (1966).

Outlawing discrimination in public accommodations was generally thought not to threaten legitimate rights of association. Even at early common law innkeepers and common carriers were obligated to accept any person seeking accommodations. Sec, $c . g$., Jackson v. Rogers, 89 Eng. Rep. 968 (K.B. 1683); People v. King, 110 N.Y. 418, 427, 18 N.E. 245, 248 (1888); J. STORY, Commentaries oN THE LAw of B.illaient $\$ 476$ (9th ed. 1878). See generally Bell v. Maryland, 378 U.S. 226, $296-300$ (1964) (Goldberg, J., concurring). This right of access, however, did not extend to places of public amusement and entertainment. See Madden v. Qucens County Jockey Club, 296 N.Y. 249, 72 N.E.2d 697, cert. denied, 332 U.S. 761 (1947).

In the sit-in cases, the willingness of the lunch counters, restaurants and motels to accept any white person nullified their claim to freedom to discriminate. See generally Bell v. Maryland, supra at 314 (Goldberg, J,, concurring); Sengstock \& Sengstock, Discrimination: A Constitutional Dilemma, 9 WM. \& MARY L. REv. 59, 119 (1967).

8. 42 U.S.C. $\$ 2000 \mathrm{a}$ (e) (1970). 
bers of Congress felt that the exemption was included to avoid infringing upon rights of association and privacy. ${ }^{\circ}$ But the exemption also reflects the simple fact that the harm to which the legislation was primarily addressed was discrimination in public accommodations rather than in private groups. ${ }^{10}$

After the passage of the act, a number of restaurants, amusement parks, and swimming pools sought to escape the statute by alleging private club status. ${ }^{11}$ The resulting litigation produced a substantial amount of case law which gave a strict construction to the club exemption. ${ }^{12}$ However, the exemption still represents a significant gap in the civil rights legislation.

9. See H.R. REP. No. 914, 88th Cong., 1st Sess. pt. 2, at 9 (1963) (minority report of House Judiciary Comm. on H.R. 7152, 88th Cong., 1st Sess. (1963)): "Moreover, where freedom of association might logically come into play as in cases of private organizations, title II quite properly exempts bona fide private clubs and other establishments."

10. Sen. Humphrey, for example, remarked:

Title II ... is designed to reach the most significant manifestations of discrimination.

It is carefully drafted and moderate in nature. There is no desire to regulate truly personal or private relationships... This does not mean that discrimination in the operation of such facilities is any more defensible or moral than elsewhere, but merely that discrimination in such establishments is not of major dimension, especially when compared with the other problems with which Title II and the bill as a whole deals.

110 CoNG. REC. 6534 (1964) (referring specifically to the exemption for "Mrs. Murphy's Boardinghouse").

11. See, e.g., Wall St. J., July 22, 1964, at 1, col. 4; Wash. Post, Aug. 16, 1964, § A, at 6, col. 4.

12. The courts developed a number of factors which could be examined to determine whether the alleged clubs were "truly private" or in fact "sham clubs" actually open to the (white) public. One area of inquiry has been whether there is evidence of genuine selectivity. Decisions finding clubs to be public accommodations have found significant: the absence of formal membership selection procedures, Stout v. YMCA, 404 F.2d 687, 688 (5th Cir. 1968); failure to reject a significant number of white applicants, Nesmith $v$. YMCA, 397 F.2d 96, 101 (4th Cir. 1968); extending club facilities to nonmembers in disregard of club bylaws, United States v. Jack Sabin's Private Club, 265 F. Supp. 90, $92-93$ (E.D. La. 1967); the absence or insubstantiality of dues and exceedingly large membership lists, Bradshaw v. Whigham, 11 RACE REL. L. Rer. 934, 936 (S.D. Fla. 1966). Several courts have cited advertising as evidence of a lack of selectivity. See, e.g., United States v. Jordan, 302 F. Supp. 370, 376 (E.D. La. 1969).

Other decisions have looked to the extent to which the membership exercised rights of control over the alleged clubs. Courts denying the exemption have considered as relevant evidence that: members did not own club facilities, Daniel v. Paul, 395 U.S. 298, 301 (1969); profits from the use of club facilities were retained by the operator, United States v. Richberg, 398 F.2d 523, 527 (5th Cir. 1968); members had no control over the operations of the establishment, Wright v. Cork Club, 315 F. Supp. 1143, 1155 (S.D. Tex. 1970).

Some courts have looked to the intent of the organizers of the club, denying an exemption where the club was formed to evade the public accommodations law. See, e.g., United States v. Northwest La. Restaurant Club, 256 F. Supp. 151, 152-53 (W.D. La. 1966). Some purpose other than the exclusion of blacks from an otherwise public facility has been required. United States v. Johnson Lake, Inc., 312 F. Supp. 1376, 1381 (S.D. Ala. 1970). Only rarely have private club claims been sustained. See Evans v. Laurel Links, Inc, 261 F. Supp. 474, 477 (E.D. Va. 1966) (dictum; although golf course must accept black players and spectators, golf association with 75 members, not a party defendant, would be exempt). See generally Note, Public Accommodations Laws and the Private Club, 54 Gro. L.J. 915 (1966) (similar cases applying state laws); Comment, Public Accommodations: What Is a Private Club?, 30 MoNT. L. REv. 47 (1968); Note, The Privale Club Exemption to the Civil Rights Act of 1967: A Study in Judicial Confusion, 44 N.Y.U.L. REv. 1112 (1969). 


\section{B. The Exclusion of Private Schools}

The Fourteenth Amendment, which substantially curtailed public school discrimination, has never been extended to prohibit private school discrimination because of the required showing of state action. ${ }^{13}$ In Fourteenth Amendment cases challenging discrimination by private schools which were receiving state aid, the courts have generally noted that without the specific state involvement challenged, the Fourteenth Amendment would not reach discrimination by private schools. ${ }^{14}$

Many private schools, even if they do not receive state aid, might be considered a type of public accommodation..$^{15}$ They provide in return for a fee educational services to consumers drawn from the general public. Nevertheless, private schools were not included in the public accommodations provisions of the 1964 Civil Rights Act. ${ }^{16}$ This has resulted in virtual immunity in most jurisdictions from government prohibitions against discrimination, and private schools have consequently become a focal point of resistance to forced integration in the public schools. ${ }^{17}$

Given the blanket exemptions of private clubs and private schools from the public accommodations title, litigation under the 1964 Act to test the rights of the clubs or schools to discriminate was virtually impossible. A landmark decision of the Supreme Court in 1968, ${ }^{18}$ however, created a substantive legal basis for such action using a long forgotten statute enacted shortly after the Civil War.

13. See Civil Rights Cases, 109 U.S. 3 (1883). See generally Note, State Action: Theories for Applying Constitutional Restrictions to Private Activity, 74 Colum. L. REv. 656 (1974).

14. See, e.g., Norwood v. Harrison, 413 U.S. 455, 469 (1973). Some commentators have suggested that more liberal definitions of state action should be applied so that private schools could be ordered to desegregate. See, e.g., Note, Federal Tax Benefits to Segregated Private Schools, 68 Colum. L. Rev. 922, 926-37 (1968); Note, Post-Brown Private I'hile Schools-An Imperfect Dualism, 26 VAND. L. REv. 587, 623-24 (1973); Note, Segregation Academies and State Action, 82 YALE L.J. 1436, 1453-58 (1973).

15. Several northern and western states have civil rights statutes which treat private schools as public accommodations. See Dorsen, Racial Discrimination in "Private" Schools, 9 WM. \& MARY L. REv. 39, 47-48 (1967); note 97 infra.

16. See 42 U.S.C. $\$ 2000 \mathrm{a}(\mathrm{b})(\mathrm{l})-(4)(1970)$. Title IV of the Act authorized the Commissioner of Education to provide technical assistance in the implementation of school desegregation plans and authorized the Attorney General to bring civil suits for the desegregation of schools on behalf of parents unable to do so themselves. 42 U.S.C. $\$ S$ $2000 \mathrm{c} \cdot 2,-3,-4,-6(1970)$. The definitions limited the act to "public schools" operated by a state entity or dependent upon governmental funds. 42 U.S.C. $\$ 2000 \mathrm{c}$ (c) (1970).

Even if they had been included among the types of accommodations reached by the act, private schools "not in fact open to the public" could escape the application of the statute because the private club exemption applies to both clubs and "other establishment[s]" not open to the public. 42 U.S.C. $\$ 2000$ a(e) $(1970)$.

17. See Note, Segregation Academies and State Action, supra note 14.

18. Jones v. Alfred H. Mayer Co., 392 U.S. 409 (1968). 


\section{The Civil Rights Act of 1866}

\section{The Civil Rights Act of 1866 provides that:}

[A]ll persons ... shall have the same right ... to make and enforce contracts ... and . . . to inherit, purchase, lease, sell, hold, and convey real and personal property ... as is enjoyed by white citizens . . . . ${ }^{10}$

The debates in the Congress indicate that while some Congressmen believed that the statute would reach private discrimination, ${ }^{20}$ others thought that only disabilities imposed on blacks by state law would be reached. ${ }^{21}$ Doubt over the capacity of the Congress, under the Thirteenth Amendment's authorization to abolish slavery, 22 to enact legislation that would outlaw actions taken by the states formed one reason for the ratification of the Fourteenth Amendment in 1868.23 In order to remove constitutional doubt on this score, the 1866 Act was reenacted in $1870 .{ }^{24}$ The relevant portions of the old act are

19. Act of April 9, 1866, ch. 31, $\$ 1,14$ Stat. 27. After reenactment and codification, $\$$ 1 of the 1866 Act now appears as 42 U.S.C. $\$ \$ 1981,1982(1970)$. See note 24 infra. Note that the statute addresses the limited problem of racial discrimination against blacks rather than the broader concepts of "equal protection" for all groups developed under the Fourteenth Amendment. But see note 40 infra. The discussion herein will be limited to situations involving such discrimination against blacks.

20. See, e.g., Cong. Globe, 39th Cong., lst Sess. 475, 599 (1866) (remarks of Sen. Trumbull). See generally Note, Section 1981 and Private Discrimination: An Historical Justificalion for a Judicial Trend, 40 Geo. WASH. L. REv. 1024, 1025-33 (1972); tenBroek, Thirteenth Amendment to the Constitution of the United States, 39 CALIF. L. REv. 171, 174.99 (195I).

21. See, e.g., Conc. Glone, 39th Cong., 1st Sess. 1118-19 (remarks of Rep. Wilson), 1291 (1866) (remarks of Rep. Bingham). See also id. at 476 (Sen. Trumbull stating that the Act would have no effect in a state whose laws were not discriminatory).

The contradictory nature of the statements of the Congressmen is demonstrated from the selections used by the majority and dissenters in Jones v. Alfred H. Mayer Co., 392 U.S. 409, 422-32, 454-73 (1968). See note 31 infra.

22. U.S. CoNST. amend. XIII provides in its entirety:

Section 1. Neither slavery nor involuntary servitude, except as a punishment for crime whereof the party shall have been duly convicted, shall exist within the United States, or any place subject to their jurisdiction.

Section 2. Congress shall have power to enforce this article by appropriate legislation.

23. Hurd v. Hodge, 334 U.S. 24, 32-33 (1948). H. Flack, The Adoption of the FOURTEENTH AMENDMENT 94-95 (1908); Gressman, The Unhappy History of Civil Rights Legislation, 50 Mich. L. REv. 1323, 1329 (1952).

The language of the Fourteenth Amendment which has had the greatest impact on discrimination provides:

No state shall ... deprive any person of life, liberty, or property, without due process of law; nor deny to any person within its jurisdiction the equal protection of the laws.

U.S. Const. amend. XIV, $\$ 1$.

24. Act of May 31,1870 , ch. $114, \S \S 16,18,16$ Stat. 144. Section 1 of the 1866 Act was reenacted in $\$ 18$. The language of the 1866 Act was repeated with some alterations in $\$$ 16 of the 1870 Act. When these provisions were codified in 1874, the codifiers' historical note for what was to become 42 U.S.C. $\$ 1981$ incorrectly specified its origin as $\S 16$ of 
currently referred to as $\S 1981$ and $\$ 1982 .{ }^{25}$

For years the statute was given a narrow construction by the Supreme Court. According to the Court, the Thirteenth and Fourteenth Amendments gave Congress the power to prohibit state-imposed legal disabilities and privately imposed involuntary servitude, but not private discrimination. ${ }^{26}$ In 1948 the Court introduced a requirement that state action must be shown before a violation of the 1866 Act could be found. ${ }^{27}$ No case arising under the 1866 Act reached the Court again until Jones $v$. Alfred H. Mayer Co..$^{28}$ in 1968.

In that case Joseph Lee Jones alleged that the refusal of Mayer and the other defendants to sell him a house was racially motivated and

the 1870 Act. This led one court to conclude that $\$ 1981$ was based on the Fourteenth Amendment rather than the Thirteenth, and that "state action" was required. Cook v. Advertiser Co., 323 F. Supp. 1212 (M.D. Ala. 19'71), aff'd on other grounds, 458 F.2d 1119 (5th Cir. 1972). See Note, supra note 20, at 1036-39. The court in Cook seems to have overlooked the Supreme Court's reference in Jones $v$. Alfred H. Mayer Co. to $\$ 18$ of the 1870 Act as the source of both $\$ \$ 1981$ and 1982 and its holding that reenactment did not limit $\$ 1982$ to "state action." 392 U.S. at 422 n.28, $436-37$ (1968). For this and other reasons the view expressed in Cook has been rejected in other cases. See, e.g., Sanders v. Dobbs Houses, Inc., 431 F.2d 1097, 1099 (5th Cir. 1970), cert. denied, 401 U.S. 948 (197I).

25. The codifiers split a single sentence from the 1866 Act to form the two sections. Section 1982 became the source of a "same right" in property transactions only. 42 U.S.C. $\S 1981$ (1970):

All persons within the jurisdiction of the United States shall have the same right in every State and Territory to make and enforce contracts, to sue, be parties, give evidence, and to the full and equal benefit of all laws and proceedings for the security of persons and property as is enjoyed by white citizens, and shall be subject to like punishment, pains, penalties, taxes, licenses, and exactions of every kind, and to no other.

42 U.S.C. $\$ 1982(1970)$ :

All citizens of the United States shall have the same right, in every State and Territory, as is enjoyed by white citizens thereof to inherit, purchase, lease, sell, hold, and convey real and personal property.

26. In a decision arising from several cases challenging the Civil Rights Act of 1875, ch. 114,18 Stat. 335 , a later enacted federal public accommodations Iaw, the Supreme Court in the Civil Rights Cases, 109 U.S. 3 (1883), defined the scope of the congressional power under the post-Civil War amendments in a manner having a profound impact on all of the existing legislation. In holding the 1875 statute unconstitutional the Court ruled that congressional power under the Thirteenth Amendment was limited to eliminating "slavery and its incidents." The Court held that while this might include legislation prohibiting private persons from imposing involuntary servitude upon others, the Congress had no power to prohibit a private refusal to admit blacks to a public accommodation because "such an act... has nothing to do with slavery or involuntary servitude." 109 U.S. at 23-24.

Although the 1866 Act was not before the Court, the decision stated that the purpose of that act was the removal of legal disabilities that had formerly been imposed on slaves and freedmen. Id. at 24-25. Later decisions of the Supreme Court applied just as narrow a construction to the 1866 Act. In two cases the Court refused to apply the statute to private interference with the making of contracts because no "condition of enforced compulsory service" was involved. See Hodges v. United States, 203 U.S. 1, 16 (1906) (private acts of intimidation preventing the making of employment contracts); Corrigan v. Buckley, 271 U.S. 323, 330 (1926) (restrictive covenants controlling the resale of real estate). See generally Note, The "New" Thirteenth Amendment: A Preliminary Analysis, 82 HARv. L. REv. 1294, $1303-06$ (1969).

27. Hurd v. Hodge, 334 U.S. 24, 31 (1948). But see Jones v. Alfred H. Mayer Co., 392 U.S. 409, 420 n.25 (1968) (criticizing the Hurd Court's assertion that this requirement had been part of the holding in Corrigan $v$. Buckley).

28. 392 U.S. 409 (1968). 
a violation of $\S 1982$. The Supreme Court ruled in favor of Jones, ${ }^{29}$ holding that $\$ 1982$ "bars all racial discrimination, private as well as public, in the sale or rental of property."30 Private refusals to sell based on race were said to deny blacks the "same right as is enjoyed by white citizens." "31 The Court held that $\$ 2$ of the Thirteenth Amendment gave Congress the power "rationally to determine what are the badges and incidents of slavery and the authority to translate that determination into effective legislation."32 A conclusion that private discrimination in property transactions was such an incident of slavery was not an irrational one, according to the Court. ${ }^{33}$

In the years since Jones, the 1866 Act has become an alternative ground for the decisions in many cases based on the more recent civil rights legislation ${ }^{34}$ and has occasionally filled gaps left by these later statutes..$^{35}$ Section $1981^{30}$ has been most often applied to refusals

29. The district and circuit courts dismissed the claim because no state action had been proven. 255 F. Supp. 115, 120-21 (E.D. Mo. 1966), aff'd, 379 F.2d 33, 43-46 (8th Cir. 1967).

30. 392 U.S. at 413 (cmphasis in original).

31. Id. at 421 (ellipses omitted, emphasis in original). The Court's interpretation of the words "same right" has been criticized by several commentators. See, e.g., Henkin, Foreword: On Drawing Lines, 82 Harv. L. Rev. 63, 85-86 (1968). The Court supported this interpretation of the statute with extensive quotations from the debates in the 39 th Congress. 392 U.S. at 423-35. The majority's interpretation of the legislative history has also drawn criticism from several sources. See 392 U.S. at 457-76 (Harlan, J., dissenting); C. Fairaian, History of the Supreme Court of the United States: ReconSTRUCTION AND REunion 1864-88, at 1207-58 (1971); Ervin, Jones $v$. Alfred H. Mayer Co.: Judicial Activism Run Riot, 22 Vand. L. REv. 485, 495-97 (1969).

32. 392 U.S. at 440. This essentially overruled the earlier cases. See notes 26-27 supra. For the text of the Thirteenth Amendment, see note 22 supra.

33. 392 U.S. at $440-41$. The Court in the Civil Rights Cases, 109 U.S. 3, 24 (1883), had said that this "would be running the slavery argument into the ground."

The Court also dismissed the argument that the reenactment of $\S 1982$ in 1870 after the passage of the Fourteenth Amendment limited its reach to "state action." 392 U.S. at $436-37$.

34. The $\$ 1982$ prohibition of discrimination in property transactions provides an alternative ground in cases based on the 1968 Fair Housing statute. 42 U.S.C. $\$ \$ 3601-31$ (1970). See, e.g., Crim v. Glover, 338 F. Supp. 823 (S.D. Ohio 1972).

35. Section 1982 has provided a cause of action in several cases which would not fit under the 1968 housing statute. Discrimination before the effective date of the statute was reached in Newbern v. Lake Lorelei, Inc., 308 F. Supp. 407 (S.D. Ohio 1968). Section 1982 has helped plaintiffs circumvent various technical limitations in the 1968 Act. See, e.g., Warren v. Norman Realty Co., No. 74-1459 (8th Cir., Mar. 21, 1975) (statute of limitations-42 U.S.C. $\$ \$ 3610,3612$ (1970)); Wright v. Kaine Realty, 352 F. Supp. 222 (N.D. Ill. 1972) (\$1000 limit on punitive damages-42 U.S.C. $\$ 3612$ (c) (1970)); McLaurin v. Brusturis, 320 F. Supp. 190 (E.D. Wis. 1970) (exhaustion of remedies under state law42 U.S.C. $\$ 3610(\mathrm{~d})(1970)$ ).

Section 1982 has also been applied to discrimination outside the substantive scope of the 1968 Act. See, e.g., Johnson v. Zaremba, 381 F. Supp. 165 (N.D. Ill. 1973) (small owneroccupied rental units -42 U.S.C. $\$ 3603(\mathrm{~b})(2)(1970)$ ); Bush v. Kaim, 297 F. Supp. 151 (N.D. Ohio 1969) (single family house-42 U.S.C. $\$ 3603(\mathrm{~b})(1)(1970)$ ).

36. Although $\$ 1981$ was not before the Court, the Jones decision effectively made this statute applicable to private discrimination as well, because the Court explicitly recognized the common origin of the two sections. 392 U.S. at 422 n.28, 441-42 n.78. The Court in Jones also explicitly overruled Hodges v. United States, 203 U.S. I (1906), which had dealt only with $\$ 1981$, as "incompatible with the history and purpose of the Thirteenth 
to make contracts for employment. ${ }^{37}$ Outside of the employment context the use of the statute has been more limited, but it has been applied to the contracts involved in the purchase of a ticket to an amusement park $^{38}$ and the admission of patients to a private hospital. ${ }^{39}$ The courts are committed to the proposition that the "same right to make contracts" bars refusals to deal based on race.40

'Amendment." 392 U.S. at 441 n.78. See note 26 supra. Furthermore, the prohibition of private discrimination in addition to legal disabilities stemmed from the Court's interpretation of the term "same right" in $\$ 1982$. Section 1981 uses the same term.

37. Each circuit presented with the question has applied $\$ 1981$ to employment discrimination. See, e.g., Macklin v. Spector Freight Systems, Inc., 478 F.2d 979 (D.C. Cir. 1973); Young v. ITT, 438 F.2d 757 (3d Cir. 1971); Brown v. Gaston County Dyeing Mach. Co., 457 F.2d 1377 (4th Cir.), cert. denied, 409 U.S. 982 (1972); Sanders v. Dobbs Houses, Inc., 431 F.2d 1097 (5th Cir. 1970), cert. denied, 401 U.S. 948 (1971); Long v. Ford Motor Co., 496 F.2d 500 (6th Cir. 1974); Brady v. Bristol-Meyers, Inc., 459 F.2d 621 (8th Cir. 1972). Section $198 \mathrm{I}$ has helped plaintiffs circumvent some procedural limitations of the employment discrimination provisions of the 1964 Civil Rights Act. See note 72 infra.

38. Scott v. Young, 421 F.2d 143 (4th Cir.), cert. denied, 398 U.S. 929 (1970). Sec Williams v. Kansas City, 104 F. Supp. 848, 859 (W.D. Mo. 1952), aff'd, 205 F.2d 47 (8th Cir.), cert. denied, 346 U.S. 826 (1953) (swimming pool); Valle v. Stengel, 176 F.2d 697 (3d Cir. 1949) (same).

39. United States v. Medical Soc'y, 298 F. Supp. 145, 152 (D.S.C. 1969). In another case, Sims v. Order of United Commercial Travelers of America, 343 F. Supp. 112 (D. Mass. 1972), the court denied the defendant's motion to dismiss a $\$ 1981$ claim because plaintiff had alleged that the fraternal organization was actually primarily a seller of insurance.

40. The application of the 1866 Act to discrimination against groups other than blacks is unsettled. The statute gives "all persons" the same specified rights as "white citizens." Therefore it seems that the statute offers little to a plaintiff who is himself a white citizen. See Perkins v. Banster, 190 F. Supp. 98, 99 (D. Md. 1960), aff'd, 285 F.2d 426 (4th Cir. 1960); Marshall v. Plumbers \& Steamfitters Local 60, 343 F. Supp. 70, 72 (E.D. La. 1972). But see CoNG. GLobe, 39th Cong., lst Sess. 1413 (1866) (Sen. Trumbull stating that addition of phrase "as is enjoyed by white citizens" as suggested by House would not alter the meaning of the bill, that the rights of all persons shall be equal). See also id. at 599. Some courts, however, have indicated that the statute prohibits all racial discrimination, including such discrimination against whites. See Carter $v$. Gallagher, 452 F.2d 315, 325 (8th Cir. 1971), cert. denied, 406 U.S. 950 (1972) (modifying an order requiring an absolute preference for minority applicants to a local fire department; Fourteenth Amendment alternative ground for decision); Hollander v. Sears, Rocbuck \& Co., Civil No. H-74-398 (D. Conn., Mar. 27, 1975) (white student refused admission to internship program for minorities); WRMA Broadcasting Co. v. Hawthorne, 365 F. Supp. 577, 581-82 (M.D. Ala. 1973) (discrimination against white applicant by black employer); Gannon v. Action, 303 F. Supp. 1240, 1244 (E.D. Mo. 1969), aff'd on other grounds, 450 F.2d 1227, 1232 (8th Cir. 1971) (disruption by blacks of white church service; aff'd on basis of 42 U.S.C. $\$ 1985(3)$ (1970) only); Central Presbyterian Church v. Black Lib. Front, 303 F. Supp. 894, 899 (E.D. Mo. 1969) (disruption of white church service).

By equating the rights of "persons" and "citizens" the statute seems to prohibit discrimination based on alienage rather than race. Before Jones the use of the statute to strike down state-imposed legal disabilities on aliens was well established. See Takahashi v. Fish \&: Game Comm'n, 334 U.S. 410,419 (1948); Oyama v. California, 332 U.S. 633,640 (1948); Roberto v. Hartford Fire Ins. Co., 177 F.2d 811, 813-14 (7th Cir. 1949). Sec also Graham v. Richardson, 403 U.S. 365,377 (197l). Applying the principles laid down in Jones, some courts are now recognizing that the statute applies to private discrimination based on alienage. See Guerra v. Manchester Terminal Corp., 350 F. Supp. 529, 533-38 (S.D. Tex. 1972), modified, 498 F.2d 641, 653-54 (5th Cir. 1974) (employment discrimination); League of Academic Women v. Regents of Univ. of Calif., 343 F. Supp. 636, 639-40 (N.D. Calif. 1972) (dictum). Some cases say that the statute is limited solely to racial discrimination, apparently ignoring the alienage question. See, e.g., Georgia v. Rachel, 384 U.S. 780, 791-92 (1966); Agnew v. City of Compton, 239 F.2d 226, 230 (9th Cir. 1956), cert. denied, 353 U.S. 959 (1957). 
Although the 1866 Act has great potential for attacking discrimination in private clubs and private schools, ${ }^{41}$ that potential remains largely unrealized. Two cases involving the application of the statute to allegedly private clubs have reached the Supreme Court. But in both Sullivan v. Little Hunting Park, Inc., ${ }^{42}$ and Tillman v. WheatonHaven Recreation Association ${ }^{43}$ the conflict between the broad sweep of the revitalized 1866 Act and the associational interests of club members was not resolved. In both cases the Supreme Court held that the clubs could not have qualified as private clubs under the 1964 public accommodations statute. ${ }^{44}$ They were subject to the 1866 Act because, having "no plan or purpose of exclusiveness other than race," they were not "truly private." 45 These cases establish a rule that qualification as a private club under the public accommodations case law is a necessary condition to the grant of any theoretical exemption from the 1866 Act. But the Supreme Court has not yet been forced to decide whether being a "truly private" club for the purposes of the 1964 Act is also a sufficient condition for an exemption from $\S 1981 .{ }^{46}$

The statute has not yet been applied to discrimination against white citizens based on their religion or national origin. See Jones v. Alfred H. Mayer Co., 392 U.S. 409, 413 (1968); Marshall v. Plumbers \& Steamfitters Local 60, supra at 72; Schetter v. Heim, 300 F. Supp. 1070, 1073 (E.D. Wis. 1969). But see Sanchez v. Trans World Airlines, Inc., 499 F.2d 1107, 1108 (10th Cir. 1974) ("On its face at least it seems thin to hold that because a Spanish speaking citizen is a Caucasian, thereby he cannot take advantage of this statute"; remanded, in part for consideration of this question).

The statute has been generally held not to apply to sex discrimination. See League of Academic Women v. Regents of Univ. of Calif., supra at 640; Williams v. San Francisco Unified School Dist., 340 F. Supp. 438,440 (N.D. Calif. 1972); Fitzgerald v. United Methodist Community Center, 335 F. Supp. 965, 966 (D. Neb. 1972). But see Long v. Sapp, 502 F.2d 34, 39 \& n.2, 40 (5th Cir. 1974) (assuming that Title VII case law on sex discrimination is applicable to $\$ 1981$ and remanding for determination of a sex discrimination claim).

41. The existence of contracts in these situations seems well established. See, e.g., Olzman v. Lake Hills Swim Club, Inc., 495 F.2d 1333, 1339 (2d Cir. 1974) (entry to club pool after payment of fee constitutes a contract); North Dakota v. North Cent. Ass'n, 23 F. Supp. 694, 699 (E. D. IIl.), aff'd, 99 F.2d 697 (7th Cir. 1938) (membership in an association constitutes a contract); Asheville School for Training in Christian Leadership, 269 Ill. App. 365, 369 (1933) (acceptance of written application for enrollment in a private school constitutes completed contract).

42. 396 U.S. 229 (1969).

43. 410 U.S. 431 (1973).

44. Ste pp. I142-43 supra.

45. The Court in Sullivan adapted this test from the decision in Daniel v. Paul, 395 U.S. 298, 301-02 (1969), which had refused to apply the private club exemption to the "Lake Nixon Club" in a case arising directly under 42 U.S.C. $\$ 2000$ a. 396 U.S. at 236. This test was subsequently applied in Tillman. 410 U.S. at 438 . See also Olzman v. Lake Hills Swim Club, Inc., 495 F.2d 1333, 1336 (2d Cir. 1974). These cases avoid serious consideration of associational interests by relying on the strong presumption which has developed in public accommodations case law that offering to serve the general public negates a right to discriminate, while leaving open the possibility that "truly private" clubs might be exempt from $\$ 1981$. See notes 7 , 12 supra.

46. The lower courts in both Sullivan and Tillman had held $\$ \$ 1981-82$ inapplicable because a private club was involved. The Supreme Court in Tillman specifically noted that its decision did not reach that question. Two district courts have assumed that $\$$ 
Section 1981 was found to apply to refusals to admit young black students to all-white private schools in two significant recent cases. ${ }^{47}$ In Riley v. Adirondack Southern School for Girls ${ }^{4}$ the court indicated in dictum a readiness to apply $\S 1981$ to a school which was "truly private," but the associational issue was not reached because the plaintiffs could not make the threshold showing that their exclusion was based solely on race. ${ }^{49}$ In Gonzales v. Fairfax-Brewster School, Inc. ${ }^{50}$ the district court borrowed the "truly private" rubric from the Sullivan and Tillman decisions and found that the school could not qualify as such..$^{51}$ This finding implicitly likened the school to a public accommodation open to the public, and the court thereby avoided resolving the conflict between the Thirteenth Amendment legislation and associational interests just as the Supreme Court had done. ${ }^{52}$ But the district court's opinion indicated that it may have applied the "plan or purpose of exclusiveness other than race" test incorrectly, looking to the specific instance of discrimination rather than to the

1981 cannot be applied to secure membership in a private organization. See Solomon $v$. Miami Woman's Club, 359 F. Supp, 41, 44 (S.D. Fla. 1973); Sims v. Order of United Commercial Travelers of America, 343 F. Supp. 112, 113-14 \& n.1 (D. Mass. 1972).

47. In addition to these cases, the district court in Grier v. Specialized Skills, Inc., 326 F. Supp. 856 (W.D.N.C. 1971), held that $\$ 1981$ prohibited a refusal to admit blacks to a private barber school. While the court noted that private associational interests might be threatened in some applications of the statute, it saw no such threat in this case. Nothing in the decision indicates whether the school was "truly private" or "in fact open to the public."

48. 368 F. Supp. 392 (M.D. Fla. 1973), appeal docketed, No. 74-1976 (5th Cir., Apr. 15, 1974).

49. The black applicant was allowed to complete the application procedures, and the court found from the evidence that the rejection was based on other, nonracial criteria. The court said that it was required to resolve the question which went unanswered in Tillman because the defendant school was "truly private." 368 F. Supp. at 397 \& n.6, 7. In fact, the court did not answer that question because in Riley the exclusion was not based solely on race as it had been in Tillman. In the absence of racial discrimination $\$$ 1981 is not applicable regardless of the nature of the group. But see note 40 supra. Because the only admissions requirements involved the judgment of the headmaster, the rejection was based on subjective criteria. See note 148 infra.

50. 363 F. Supp. 1200 (E.D. Va. 1973), aff'd in relevant part sub nom. McCrary v. Runyon, No. 73-2348 (4th Cir., Apr. 15, 1975) (en banc). The district court decision sparked a great deal of comment. See, e.g., Note, Desegregation of Private Schools: Section I981 as an Alternative to State Action, supra notc 3; Note, The Desegregation of Privalc Schools: Is Section 1981 the Answ'er?, supra note 3; 11 Hous. L. Rcv. 69I (1971); 7 L.oY. L.A.L. Rev. 634 (1974); 45 Miss. L.J. 246 (1974); 42 U. Civ. L. Rev. 767 (1973); 122 U. P.A. L. REv. 471 (1973); 8 U. Rich. L. REv. 285 (1974); 26 VAND. L. REv. 1307 (1973).

51. In another pending private school case the school has stipulated that it has "no plan or purpose of exclusiveness other than race," or in effect that it is not "truly private." See Brown v. Dade Christian Schools, Civil No. 73-1313 (S.D. Fla., filed Aug. 6, 1973). The school has, however, raised a freedom of religion defense for its discrimination. See pp. 1461-62 infra.

On May 28, 1975, Judge Eaton rendered a decision on the $\$ 1981$ and religion issues in favor of the plaintiffs in an oral opinion. Further proceedings were scheduled to determine the remedies to be ordered. Sec Tampa Tribunc, May 29, 1975, at 10-1, col. I.

52. See note 45 supra. 
overall admissions policy of the school.53 If so, the court's action would effectively eliminate the "truly private" defense left open in Sullivan and Tillman by merging it with the primary issue of whether an exclusion based solely on race had occurred. Following this approach, the court of appeals held even more unequivocally that an explicit racial exclusion by any private school would violate the statute. ${ }^{54}$ In

53. The opinion stated:

Although both schools claim to have strictly established criteria for enrollment, the end result of their admission policies as applied to both Colin and Michael [the black plaintiffs] evidences no "plan or purpose of exclusiveness" for selection of students

"other than race." ... [citing Sullivan v. Little Hunting Park].

363 F. Supp. at 1204 (last emphasis in original). But see id.: "[T] these schools was open to every white child." (emphasis added).

A conclusion that the schools were not "truly private" based on the overall admissions policies might have been appropriate. The fact that the schools excluded some potential white applicants through academic and other requirements would not make them necessarily "truly private." In both Sullivan and Tillman some potential white applicants were excluded by geographic residency requirements and a requirement of formal board or membership approval. 396 U.S. at 234; 410 U.S. at 438 . In Tillman there was a ceiling on the total number of memberships. 410 U.S. at 438 . Yet neither club was sufficiently exclusive to be "truly private." See Olzman v. Lake Hills Swim Club, Inc., 495 F.2d 1333 , 1336 (2d Cir. 1974) (club with 110 families out of 2300 in community and requirement of committee approval of applicants not "truly private"). The court could hold that the schools' admissions requirements did not reflect sufficient social exclusiveness to make them "truly private." Also the fact that the schools advertised to the general public could be given substantial weight. See United States v. Jordan, 302 F. Stupp. 370, 376 (E.D. La. 1969); note 12 stipra.

54. The court of appeals majority opinion stated:

It is contended here...that $\$ 1981$ confers no right of action unless the contract denied the aggrieved person was open to all white people.... It is ... true that admission to the school is not open to all white people because there are academic, financial and other restrictions upon admission. Within the qualified class, however, there is no other limitation upon the admission of white applicants up to the school's capacity.

We may not read $\$ 1981$ so restrictively as the schools would have us to do it. The school may not refuse with impunity to accept an otherwise qualified black applicant simply because it declines to admit unqualified white applicants. The section is violated as long as the basis of exclusion is racial, for it is then clear that the black applicant is denied a contractual right which would have been granted to him if he had been white.

McCrary v. Runyon, No. 72-2348 (4th Cir., Apr. 15, 1975), slip opinion at 10-11. This passage could be taken to mean that "truly private" schools are subject to $\$ 1981$, thus answering the question left open in Tillman and Sullivan with regard to clubs. The only passage which deals with the "truly private" issuc, however, evidences the same misapplication of that test which the district court seems to have employed:

Indeed, $\$ 1981$ does not purport to reach all private associations. It reaches only those which evidence "no plan or purpose of exclusiveness" other than race. Sullivan $v$. Little Hunting Park, supra. Private associations having non-racial criteria for the selection of members may apply their criteria, even if it results in a disproportionate impact upon the members of one race. It is only when blacks are excluded because they are black, or denied a right to contract which would be granted were they white, that $\$ 1981$ is violated.

Slip opinion at 14 (emphasis added). The court seems to take the Sullivan test as determining only whether racial discrimination has taken place. Cf. pp. 1449-50 supra; note 53 supra. The court also seems incorrect in citing Sullivan for the proposition that $\$ 1981$ reaches only groups with "no plan or purpose of exclusiveness." Sullivan and Tillman specifically left open the possibility that $\$ 1981$ might reach groups with such exclusiveness. See note 16 supra.

The court could have reached the same result by holding explicitly that even groups which are "truly private" are subject to $\$ 1981$ or that the "truly private" distinction is 
eliminating the possibility that some "truly private" schools could continue legally to discriminate on the basis of race, the court of appeals in this case necessarily became the first to face squarely the conflict between the Thirteenth Amendment legislation and associational interests. $^{55}$

\section{Section 1981 and Group Rights: The Limits of Present Law}

The conflict caused by the application of $\$ 1981$ to private groups raises the question of the legal status of the right to discriminate claimed by these groups. If they could cite no significant legal doctrine supporting their discrimination, the courts could apply $\$ 1981$ with full vigor. Conversely, if that discrimination was clearly protected by congressional passage in 1964 of the private club exemption or by the Constitution, these groups could be routinely exempted from $\S 1981$. But the law supporting either of these propositions is far from conclusive. The courts therefore cannot rely on existing legal doctrine to escape the ultimate task of formulating new doctrine reconciling the conflicting constitutional principles.

\section{A. The Private Club Exemption as an Implied Partial Repeal of the Civil Rights Act of 1866}

If the exemption in the 1964 Act of "private clubs and other establishments not in fact open to the public" also applied to the 1866 Act, clubs and schools which could meet that test could continue to discriminate until new Thirteenth Amendment or state police power ${ }^{5 i}$

inapplicable where schools rather than clubs are involved. Alternatively, the court could have decided the case narrowly, finding the schools not "truly private" and avoiding much of the concern for associational interests by leaving the possibility open that more exclusive schools could escape $\$ 1981$. See note 53 supra.

55. The majority and dissenting opinions represent the first actual application of several of the legal and policy arguments discussed herein. See notes $76,77,81,87,95$, $121,144,146$ infra.

56. The states have recently indicated increasing interest in moving against private club discrimination. A Maine statute prohibits discrimination by holders of state licenses to dispense "food, liquor or any service," corporations chartered under Maine law, and corporations authorized to do business in the state. ME. REv. STAT. ANN. tit. 17, $\$ 1301-A$ (Supp. 1974). See also Ill. ANN. STAT. ch. 43, \$ 133 (Smith-Hurd 1944); N.M. STAT. ANN. $\$ 46-10-13.1$ (Supp. 1973). The refusal of the Maine State Liquor Commission to renew the liquor licenses of 15 Elks lodges was upheld in B.P.O.E. Lodge No. $2043 \mathrm{v}$. Ingraham, 297 A.2d 607 (Me. 1972), appeal dismissed, 411 U.S. 924 (1973). The opinion has been criticized for ignoring the possibility that by requiring a waiver of associational freedom the statute imposes an unconstitutional condition on the issuance of licenses. See 7 SurFoLk U.L. REv. 1069, 1074-75 (1973). This issue has been overlooked in many similar cases. See pp. 1463-64 infra. In future cases, however, Ingraham might be distinguishable because it involved the unique power of the state under the Twenty-first Amendment to regulate liquor use. Cf. California v. LaRue, 409 U.S. 109 (1972) (state power to prohibit in bars sexual displays otherwise protected as First Amendment expression). See Note, The Scope of Permissible State Interference with Racial Discrimination by Private Fraternal Organizations, 4 RuT.-CAM. L.J. 338, 353-60 (I973); 7 SUFFolK U.L. REv. 1069, $1081-82$ (1973). 
legislation ${ }^{57}$ brought them within the reach of antidiscrimination requirements. The argument is a plausible one which has been sustained in court. The lower courts in both Sullivan ${ }^{58}$ and Tillman ${ }^{59}$ refused to apply the 1866 Act because they found the organizations to be bona fide private clubs. The court of appeals in Tillman specifically held that the private club exemption "of necessity operates as an exception to the Act of 1866 in any case where that Act prohibits the same conduct which is saved as lawful by the terms of the 1964 Act." " The court's conclusion has received support in the commentary on the case, ${ }^{01}$ but, as noted above, the Supreme Court specifically refused to consider this question. ${ }^{62}$

While the conclusion that the private club exemption repealed part of the broad scope of the 1866 Act is plausible, it is hardly beyond dispute. The case law on implied repeals generally requires a showing that the two provisions are in irreconcilable conflict and that the intent of the legislature was for repeal. ${ }^{63}$ Since the broad sweep of the 1866 Act was not known to the legislators in 1964, conscious intent to limit the earlier act did not exist. ${ }^{64}$ Determining whether Con-

57. A plaintiff might bring a civil suit against a group exempt from $\$ 1981$ on the basis of the Thirteenth Amendment alone. Cf. Bivens v. Six Unknown Named Agents of Federal Bureau of Narcotics, 403 U.S. 388 (1971) (damages recoverable for violation of the Fourth Amendment on the strength of the amendment alone). See Larson, supra note 3 , at 505 . But a plaintiff might find it impossible to establish that private group discrimination amounts to "slavery or involuntary servitude" or a vestige thereof without the kind of congressional finding to that effect relied on in Jones.

58. Sullivan v. Little Hunting Park, Inc., 396 U.S. 229 (1969). The opinion of the Virginia trial court in Sullivan is unreported, but the U.S. Supreme Court opinion specifically referred to that court's finding and reversed it. Id. at 236.

59. Tillman v. Wheaton-Haven Recreation Ass'n, Inc., 451 F.2d 1211 (4th Cir. 1971).

60. $451 \mathrm{~F} .2 \mathrm{~d}$ at 1214 . The majority opinion by Judge Haynsworth drew a vigorous dissent from Judge Butzner on the grounds that the association was not a bona fide private club. He felt the implied repeal question was therefore irrelevant. Id. at 1222-25. In dissenting from the denial of a rehearing en banc, two other judges agreed and objected in addition to the holding on implied repeal when the question had not been briefed and argued. Id. at 1225.

61. See Note, Private Clubs: The Right to Discriminate in Admissions Policies, $34 \mathrm{U}$. PITT. L. REV. 447 (1973); See generally Note, Private Clubs Expressly Excepted from the Coverage of the Civil Rights Act of 1964 Constitute an Exemption from the Civil Rights Act of 1866,6 GA. L. REv. 813, 821 (1972).

62. 410 U.S. at $438-39$. The district court in Gonzales v. Fairfax-Brewster School, Inc., 363 F. Supp. 1200, 1205 (E.D. Va. 1973), aff'd in relevant part sub nom. McCrary v. Runyon, No. 73-2348 (4th Cir., Apr. 15, 1975), slip opinion at 32-33, however, rejected the implied repeal argument with no explanation. The court of appeals did not mention the specific issue, although the dissenting opinion noted that the Congress did not extend the legislation of 1961 to cover private schools.

63. Posadas v. National City Bank, 296 U.S. 497, 503 (1936). As a general rule, repeals by implication are "not favored." United States v. Borden Co., 308 U.S. 188, 198 (1939). The parallel question of implied repeal of $\$ 1981$ by the employment discrimination provisions was considered in Note, Is Section 1981 Modified by Title III of the Civil Rights Act of 1961?, 1970 DukE L.J. 1223.

64. See Brief for the United States as Amicus Curiae, at $31 \mathrm{n.14}$, Sullivan v. Little Hunting Park, Inc., 396 U.S. 229 (1969). In hearings on the act, $\$ \S$ 1981-82 were mentioned, however, as at least prohibiting state-sanctioned discrimination in places of public accommodation. See Hearings on S. 1732 before the Senate Committee on Commerce, 88th Cong., lst Sess., 134 (1963) (remarks of Sen. Prouty and Att'y Gen. Kennedy). 
gress would have limited the act if they had this knowledge would be highly speculative. ${ }^{65}$

Because of this special circumstance, a clear irreconcilable conflict between the two acts is probably necessary to constitute implied repeal. An irreconcilable conflict exists only if the private club exemption must be interpreted as making discrimination by private establishments lawful. ${ }^{60}$ However, it is at least equally plausible to read the exemption merely as a definition of the scope of the remedies provided by the 1964 Act. ${ }^{67}$ No language in the act specifically singles out any private discrimination which "shall be lawful." In addition, a saving clause was included, providing that "nothing in this subchapter shall preclude any individual ... from asserting any right based on any other Federal or State law not inconsistent with this subchapter ...."'s8 Nonetheless, since only laws which are "not inconsistent" are saved, the correct meaning of the private club exemption still must be determined. ${ }^{69}$ The legislative history of the private club exemption is sparse, supporting neither interpretation conclusively. ${ }^{70}$

The argument for implied repeal is hindered by the track record of the same argument with regard to other portions of the recent civil rights legislation. In Jones the Court rejected the suggestion that limitations in the 1968 Fair Housing Act worked to limit the scope of $\S 1982$. The Court rejected the notion that the 1968 Act should su-

65. It is true that Congress, thinking it was writing on a clean slate, chose not to reach private group discrimination. But from the legislative history, it is virtually inpossible to determine whether the dominant intent was positively to protect private group discrimination or to facilitate a swift solution in the public accommodations area by withholding consideration of this more problematic area until a later date. See notes 9 , 10 supra. Viewed differently, even though there may have been insufficient support to attack private group discrimination in the 1964 Congress, this does not mean that there would have been enough support to limit $\$ 1981$ if it had then been determined to reach private discrimination. Cf. Note, supra note 63, at 1235: "Had Congress been aware of the existence of a section 1981 action [against employment discrimination]; necessary votes could probably not have been mustered to repeal or modify that statute."

The need to agonize over exactly what Congress meant to do in 1961 is lessened by the fact that regardless of the decision on implied repeal, Congress retains the power to amend or repeal the 1866 Act. This possibility was noted in some of the comment sparked by Jones. See Larson, supra note 3, at $510 \&$ n.78. Failure to amend $\$ \$ 1981-82$ suggests approval of the direction taken in recent judicial opinions.

66. See p. 1453 supra.

67. The exemption uses the phrase "the provisions of this stbchapter shall not apply to...." See Note, Constitutional Law-Prizate Club Discrimination, supra note 3, at 60.4 \& $\mathrm{n.49}$ (the exemption is not a "license to discriminate: rather it is a directive that the remedy for discrimination is not to be had under that particular federal law").

68. 42 U.S.C. $\$ 2000 \mathrm{a}-6$ (b) (1970).

69. See Note, Private Clubs: The Right to Discriminate in Admissions Policies, supra note 61 , at $450-51$.

70. See note 65 supra. At one point Sen. Humphrey, one of the floor managers, indicated that the exemptions reflected a desire to deal only with major problems. See note 10 supra. On another day he said: "I do not believe there should be a federal law which provides that a private club should be managed this way, or managed that way." 110 Cong. REC. 6008 (1964). 
persede $\$ 1982$ entirely because of "the vast differences" in the remedies and operative effects of the two acts. ${ }^{71}$ The courts of appeals have uniformly rejected the contention that limitations in the employment discrimination provisions of the 1964 Act limit $\$ 1981 .^{72}$ And in Sullivan the Court rejected the defendant's argument that the 1866 Act was completely superseded by the 1964 public accommodations statute, adopting the reasons given in Jones regarding the 1968 Act. ${ }^{73}$ Taken together these cases amount to a substantial body of precedent disfavoring the proposition that the legislation of the 1960's worked a repeal of that passed a century earlier.

\section{B. A Constitutional Right to Discriminate?}

The difficulty of resolving the conflict raised by the application of $\$ 1981$ to private groups might be avoided if the courts could cite definitive law establishing a constitutional right for these groups to

71. 392 U.S. at $415-1 \%$. The Court also referred to a saving clause in the 1968 Act. Id. at 416 n.20. See 42 U.S.C. $\$ 3615(1970)$. The value of Jones as precedent on the implied repeal question regarding the $1964 \mathrm{Act}$ is limited, however, by the Court's additional reliance in Jones on the fact that the potential for a reformulation of $\$ 1982$ by the Supreme Court had been brought to the attention of the Congress before the 1968 legislation was passed. 392 U.S. at $415-17$.

72. See cases cited in note 37 supra. Several circuits have rejected the argument that a complaint must be filed with the Equal Employment Opportunity Commission (EEOC) as required by Title VII to give the court jurisdiction in a $\$ 1981$ case. See Gresham v. Chambers, 501 F.2d 687, 690-91 (2d Cir. 1974); Long v. Ford Motor Co., 496 F.2d 500, 503-04 (6th Cir. 1974); Macklin v. Spector Freight Systems, Inc., 478 F.2d 979, 996 (D.C. Cir. 1973); Caldwell v. National Brewing Co., 443 F.2d 1044 (5th Cir. 1971), cert. denied, 405 U.S. 916 (1972); Young v. ITT, 438 F.2d 757, 762-63 (3d Cir. 1971). But see Penn v. Schlesinger, 497 F.2d 970 (5th Cir. 1970) (en banc), petition for cert. filed, 43 U.S.L.W. 3310 (U.S. Nov. 26, 1974) (remedies available before Civil Service Commission under Commission regulations must be exhausted before $\$ 1981$ action can be maintained against federal officials). One circuit has imposed a requirement for a showing of a "reasonable excuse" for a failure to exhaust EEOC remedies. See Waters v. Wisconsin Steel Works of Int'l Harvester, 427 F.2d 476,487 (7th Cir.), cert. denied, 400 U.S. 911 (1970). This requirement has been rejected in the other circuits, and recently the Seventh Circuit expressed a willingness to abandon it. See Waters v. Wisconsin Steel Works of Int'l Harvester, 502 F.2d 1309, 1315 (7th Cir. 1974) (on appeal after remand).

Section 1981 has also made possible actions which would have been barred by the special statute of limitations in Title VII. See Brady v. Bristol-Meyers, Inc., $459 \mathrm{~F} .2 \mathrm{~d} 621$, 621-22 (8th Cir. 1972); Boudreaux v. Baton Rouge Marine Constr. Co., 437 F.2d 1011 (5th Cir. 1971). See also Guerra v. Manchester Terminal Corp., 498 F.2d 641, 648 (5th Cir. 1974) (filing complaint with EEOC tolls statute of limitations applicable to $\$ 1981$ ); Franks v. Bowman Transp. Co., 495 F.2d 398, 406 (5th Cir. 1974), cert. granted, 95 S. Ct. 1421 (1975) (same, but defendant can raise the defense of laches).

See generally Note, Federal Power to Regulate Private Discrimination: The Revival of the Enfarcement Clauses of the Reconstruction Era Amendments, supra note 3, at 480-85.

73. The Court cited specifically the saving clause and the administrative machinery provided in the new act. 396 U.S. at 23\%-38. That this holding in Sullivan did not, however, conclusively determine the question of the application of the private club exemption as a limitation on the $1866 \mathrm{Act}$ is evident from the Court's decision four years later in Tillman. The Tillman Court specifically stated that the question had not been answered in Sullivan and that it was equally unnecessary to answer it in that case. 410 U.S. at $438-39$. 
discriminate. An examination of the relevant cases, however, reveals that no such right clearly exists.

\section{The Dicta}

Dicta in several Supreme Court cases have indicated that private groups may have a constitutionally protected right to discriminate. In distinguishing public accommodations from private groups in his concurring opinion in Bell v. Maryland, Justice Goldberg stated:

Prejudice and bigotry in any form are regrettable, but it is the constitutional right of every person to close his home or club to any person or to choose his social intimates and business partners solely on the basis of personal prejudices including race. These and other rights pertaining to privacy and private association are themselves constitutionally protected liberties. ${ }^{74}$

The dicta in Bell and other Fourteenth Amendment cases might better be characterized as explanations for the limited reach of that amendment than as carefully thought out descriptions of private activity absolutely immune from government proscriptions of discrimination in the future. During the period when the major thrust of the developing civil rights law was the Fourteenth Amendment, this associational freedom might have been thought of as deriving automatically from the "state action" limitation of that amendment. ${ }^{75}$ Therefore these dicta may have lost their validity when the Thirteenth Amendment was specifically held to reach private discrimination in 1968 . That development has brought this freedom of association into direct conflict with prohibitions on private discrimination. If freedom of association is to prevail, more affirmative constitutional support will

74. 378 U.S. 226, 313 (1964). Justice Douglas's opinion relied on the home as the locus of that right:

The home of course is the essence of privacy, in no way dedicated to public use, in no way extending an invitation to the public.... The facts of these sit-in cases have little resemblance to any institution of property which we customarily associatc with privacy.

Id. at 253. See also Lombard v. Louisiana, 373 U.S. 267, 274 (1963) (Douglas, J., concurring).

75. Note, supra note 56 , at 351 . This view was expressed by Justice Harlan in his concurring opinion in Peterson v. Greenville, 373 U.S. 244, 250 (1963):

[The state action] limitation on the scope of the prohibitions of the Fourteenth Amendment serves several vital functions in our system. Underlying the cases involving an alleged denial of equal protection by ostensibly private action is a clash of competing constitutional claims of a high order: liberty and equality.... This liberty would be overridden, in the name of equality, if the strictures of the Amendment were applied to governmental and private action without distinction. 
be needed than the negative implications drawn from the Fourteenth Amendment. In a case actually presenting this conflict, the Court might draw the right to discriminate more narrowly than the dicta suggest.

Nonetheless, the Court has persisted in making the same sorts of statements in Fourteenth Amendment cases decided since Jones. ${ }^{76}$ These later statements may suggest that some members of the Supreme Court would hold that private groups do have a constitutional right to discriminate, but they hardly amount to binding precedent for such a conclusion. ${ }^{77}$ If such a right exists, it would have a much stronger basis in the decisions of cases in which the right of free association was directly at issue.

76. In Norwood v. Harrison, 413 U.S. 455,469 (1973), the Court referred to discrimination by private schools receiving state aid:

Such private bias is not barred by the Constitution, nor does it invoke any sanction of laws, but neither can it call on the Constitution for material aid from the State. (emphasis added). The italicized phrase could be taken as dictum on the reach of $\S$ 1981. See McCrary v. Runyon, No. 73-2348 (4th Cir., Apr. 15, 1975), slip opinion at 43 (Russell, Field, and Widener, JJ., concurring and dissenting). The suggestion that private school discrimination is constitutionally protected was weakened, however, by another statement in the opinion. To the schools' argument that if they had a right to discriminate, the state could not require a waiver of that right as a condition of state aid, the Court responded:

Invidious private discrimination may be characterized as a form of exercising freedom of association protected by the First Amendment, but it has never been accorded affirmative constitutional protections.

Id. at 470 . Elsewhere in the opinion the Court acknowledged congressional power to reach private discrimination under the Thirteenth Amendment and stated specifically that the right of the schools to discriminate per se was not an issue in the case. Id. at $457-58,470$.

In his dissent in Moose Lodge No. 107 v. Irvis, 407 U.S. 163, 179.80 (1972), Justice Douglas (joined by Justice Marshall) stated:

My view of the First Amendment and the related guarantees of the Bill of Rights is that they create a zone of privacy which precludes government from interfering with private clubs or groups.... Government may not tell a man or woman who his associates must be. The individual may be as selective as he desires.

The balance of the opinion made clear Douglas's view that these rights to discriminate, however important they might be, disappeared when the club accepted a liquor license from the state of Pennsylvania.

Recently, in Gilmore v. City of Montgomery, 417 U.S. 556 (1974), the Supreme Court quoted approvingly Douglas's Moose Lodge dictum, but countered it with the statement in Norwood that a right to discriminate was not entitled to "affirmative constitutional protection." The case held that the grant by the city of exclusive use of some city recreational facilities to discriminating private schools was properly enjoined as violative of the Fourteenth Amendment, but that on the basis of the record the grant of nonexclusive use of such facilities did not violate that amendment. The decision with respect to nonexclusive use rested on the conclusion that there was no violation of the Fourteenth Amendment rather than on a constitutional right of schools both to discriminate and to use the facilities. See also Wesley v. Savannah, 294 F. Supp. 698, 701 (S.D. Ga. 1969).

77. The dissenting judges in McCrary v. Runyon, No. 73-2348 (4th Cir., Apr. 15, 1975), slip opinion at $29,35-36,42-43$, would have held $\$ 1981$ inapplicable to private schools primarily on the strength of the statements in Norwood, Moose Lodge, and Gilmore. The majority, on the other hand, distinguished Norwood and ignored the other cases. Id. at $14-15$. 


\section{Legal Doctrines Which Might Support a Right to Discriminate}

Freedom of association. Freedom of association ${ }^{78}$ evolved to protect the ability of an individual to join ${ }^{79}$ with others for the expression or promotion of political ideas. ${ }^{80}$ This freedom of association has little to do with a right to exclude others on the basis of race. ${ }^{81}$ Indeed, the right to exclude arguably impairs the freedom to associate of the person who wants to join..$^{82}$ Most schools and social clubs are apolitical and would find it difficult to prove that they require a right to discriminate for the purposes of political expression. ${ }^{33}$

Right of privacy. Because the freedom of association cases did not deal with the exclusion question, some commentators have suggested that the question of a right to discriminate could be better conceptualized as deriving from a right of privacy. ${ }^{8 *}$ Supreme Court cases have established this right to freedom from government intrusion in

78. Freedom of association was first formally recognized in NAACP v. Alabama, 357 U.S. 449 (1958), where the Court struck down a state statute compelling the disclosure of membership lists. See United States v. Robel, 389 U.S. 258 (1967); Gibson v. Florida Legis. Investigating Comm., 372 U.S. 539 (1963); NAACP v. Button, 371 U.S. 415 (1963); Shelton v. Tucker, 364 U.S. 479 (1960). See generally Emerson, Freedom of Association and Freedom of Expression, 74 YALE L.J. 1 (1964).

79. In NAACP v. Alabama, 357 U.S. 449 (1958), the word "association" frequently was used to mean an act rather than a group, and the right identified by the decision was referred to as "freedom to engage in association" and "freedom to associate" in addition to freedom of association. Id. at 460-61.

80. See Note, Discrimination in Private Social Clubs: Freedom of Association and Right to Privacy, 1970 Duke L.J. 1181, 1195, 1197. Freedom of association may have no status at all independent of freedom of expression. See United States v. Robel, 389 U.S. 258, 283 n.1 (196\%) (White, J., dissenting). But see Griswold v. Connecticut, 381 U.S. 479, 483 (1965) (dictum suggesting that the freedom of association includes the right to join nonpolitical groups also).

81. McCrary v. Runyon, No. 73-2348 (4th Cir., Apr. 15, 1975), slip opinion at 12. See Note, supra note 80 , at 1209 . One can imagine special cases in which the exclusion of blacks might be necessary to preserve the freedom of expression of a bona ficle political group. A White Citizens' Council, for example, might have a right to resist destruction of the organization by massive demands for membership by blacks. But the potential for such cases does not require a blanket exemption of all private groups from $\$ 1981$. The courts would probably have no greater difficulty patrolling the frontier between social clubs and political associations than they have now on the boundary between private clubs and public accommodations. See note 12 supra. Qualifying as a bona fide political association might require a showing of regular political activity such as lobbying, litigating or letter writing and regular participation by a substantial proportion of the membership in these activities.

One could argue that the act of excluding blacks from any association contains clements of expression. But such acts involve "conduct" rather than "pure expression," and are therefore entitled to less protection from state regulation. See Cox v. Louisiana, 379 U.S. 536, 555 (1965); T. EMERson, Toward a General Theory of the First AMENDMENT 60-61 (1967). The state interest underlying $\$ 1981$ could be held to outweigh the interest in free expression involved. See p. 1464 infra.

82. See Note, supra note 80 , at 1208 .

83. See Note, Freedom of Association: Constitutional Right or Judicial Technique, 40 VA. L. Rev. 730, 752 (1960); Comment, State Universities and the Discriminatory Fraternity: A Constitutional Analysis, 8 U.C.L.A.L. REv. 169, 187 (1961); note 110 infra.

84. See Emerson, supra note 78 , at 20; Note, supra note 80 , at 1209 . 
specific situations involving the family, procreation, and the home, ${ }^{85}$ but in several cases the Court has specifically refused to extend the right beyond these limited contexts. ${ }^{86}$ Therefore, while the concept of a zone of privacy might be the best foundation upon which a constitutional right to discriminate could be based, no decision has yet established that right as a matter of law. ${ }^{87}$

Parental rights to control the education of their children. In the private school context, the claim by parents or school officials of a right to discriminate based on freedom of association or privacy would require that they assert these rights on behalf of the children in the school. The adults might find it difficult to prove that the children share a prejudice as intense as their own. ${ }^{38}$ And even in the face of such proof, a court might note that racial prejudice is based on ignorance and discount the expressed associational preferences of children because of their age and capacity. In this sense, making integration possible through the use of $\S 1981$ might be seen as part of the educational mission of the state ${ }^{89}$ comparable to curriculum requirements which private schools must meet in order for the students to satisfy compulsory school attendance laws. The argument against such a result would have a stronger basis in a direct constitutional right of parents to control the education of their children.

85. See Roe v. Wade, 410 U.S. 113 (1973) (right to obtain abortion); Eisenstadt v. Baird, 405 U.S. 438 (1972) (right of unmarried couples to acquire contraceptives); Stanley v. Georgia, 394 U.S. 557 (1969) (right to possess obscene material in the home); Griswold v. Connecticut, 38I U.S. 479 (1965) (right of married couples to use contraceptives). See generally Henkin, Privacy and Autonomy, 74 Colvy. L. Rev. 1410 (1974).

86. See Roe v. Wade, 410 U.S. 113, 152-53 (1973). The right to view obscene materials in the home identified in Stanley has been held not to include the right to view them with other consenting adults in a theatre open to the public, Paris Adult Theatre $I \mathrm{v}$. Slaton, 413 U.S. 49 , $65-66$ (1973), or to import them for private use in the home, United States v. 12 200-Ft. Reels of Super $8 \mathrm{~mm}$ Film, 413 U.S. 123, 126-29 (1973). Neither of these decisions was unanimous, however. See, e.g., id. at 137 (Douglas, J., dissenting).

The concept of a privileged zone witlin the home has been held not to preclude a restrictive zoning ordinance limiting most of the available housing in a community to conventional families related by blood, adoption or marriage. Village of Belle Terre $v$. Boraas, 416 U.S. 1 (1974). See Note, The Constitutional Right to Privacy: An Examination, 69 Nw. U.L. REv. 263, 279-83 (1974).

The lower courts have limited the right of privacy in a variety of contexts. See gencrally Note, On Privacy: Constitutional Protection for Personal Liberty, 48 N.Y.U.L. REv. 670, $706-70(1973)$.

87. The majority in McCrary v. Runyon, No. 73-2348 (4th Cir., Apr. 15, 1975), slip opinion at 13, distinguished the privacy cases because they involved "certain instances when only a few people are involved in activity unintended for the public view [and in which] it is more than likely or inevitable that there is some plan or purpose of exclusiveness other than race."

88. "Young children do not discriminate against each other; that is a characteristic of maturity." Pierce v. Society of Sisters, 268 U.S. 510, 517 (1925).

89. The appearance of curriculum materials on the problem of race relations suggests that some public schools have adopted the improvement of race relations as a goal of their programs. See generally R. Ratcliffe, S. B.AUgher, R. Bonas et al, LAw in A New LAND (1972). 
In Meyer v. Nebraska $a^{90}$ and Pierce v. Society of Sisters ${ }^{91}$ the Supreme Court suggested such a right in striking down state statutes impairing the ability of parents to obtain educational services from private schools. Both decisions relied on notions of substantive due process $^{22}$ which protected the rights of parents "long freely enjoyed."

For several reasons these cases might not protect discrimination by private schools. The harm involved in those cases was the foreclosure of access to alternative educational programs offered in the private schools. Section 1981 would foreclose such opportunity only to the extent that a racially exclusionary admissions policy was part of the "educational message" 94 of the school. ${ }^{95}$ Racism and the desirability of segregation are relatively simple concepts which arguably could be communicated to children adequately at home without the necessity for a private school. More significantly, both Meyer and Pierce recognized the possibility that state interests could outweigh parental interests in some situations. ${ }^{96}$ Perhaps the best evidence that parental rights do not include the right to segregated schools is the fact that several northern and western states have statutes which prohibit discrimination in all or some private schools. ${ }^{97}$ Some of these statutes have

90. 262 U.S. 390 (1923) (invalidating a statute prohibiting the teaching in any school of foreign language to students below the ninth grade).

91. 268 U.S. 510 (1925) (enjoining the enforcement of an Oregon statute requiring all parents to enroll their children in public schools).

92. 262 U.S. at $399 ; 268$ U.S. at 518.

93. 262 U.S. at 403 .

94. Cf. Norwood v. Harrison, 413 U.S. 455, 469 (1973) (state cannot aid discriminatory schools as it does religious schools because discrimination is an inherent part of the "educational message" of the former).

95. The majority in McCrary v, Runyon, No. 73-2348 (4th Cir., Apr. 15, 1975), slip opinion at 12-13, did not even recognize this possibility, finding that "[n]othing in $\$ 1981$ impedes parents in their exercise of a choice of a private school presenting ideas or having educational methods or practices which are not available in the public schools."

96. 262 U.S. at $401-03 ; 268$ U.S. at 516.

97. See IdAho Code $\$ \S 67-5902(10) ; 67-5909(6)$ (Burns 1973); IND. ANN. STat. $\$ \S 22-9$. 1-2(a), 22-9-1-3(l) (1974); MIN. STAt. ANn. $\$ \$ 363.01$ Subd. 20, 363.03 Subd. 5 (Supp. 1974); Mont. Rev. Codes ANn. $\$ \S 64-305(4)$, 64-306(6) (Supp. 1974); N.J. STAT. IN. \$ 10:5-5(l) (Supp. 1974); S. Dak. CoMpiled LAwS ANN. $\$ \$ 20-13-1(11), 20-13-22$ (Supp. 1974); V.I. CODE ANN. tit. 10, $\$ 2$ (1966). Several of these statutes are based on the Comprehensive Anti-Discrimination Act promulgated by the National Conference of Commissioners on Uniform State Laws (1966). See also MAss. ANN. LAws ch. I51C, § 1(b) (Supp. 1974) (schools accepting admissions from the general public which are not "distinctly private"); N.Y. ExEc. LAw \$ 296-4 (McKinney Supp. 1974) (school which holds itself out to the public); WASH. REv. CODE ANN. $\$ 9.91 .010$ (1961) (schools of special instruction, nursery schools). In keeping with judicial decisions in the area of school aid, several state statutes also prohibit discrimination by schools receiving state aid. See, e.g., id.

Several other states have limited their antidiscrimination statutes primarily to post. secondary and vocational schools, with some states specifically altering the Model Act to this effect. See Colo. Rev. STat. ANN. $\$ \S 24-34-302(13), 24-34-306(f)$ (1973); Ill. ANN. Stat. ch. 163/4, \$§ 14.40, 18a (Smith-Hurd 1972); Ky. Rev. STAT. ANN. $\$ \$ 163.320(2)$, 163.340(6) (Supp. 1974); Ore. Rev. Stat. \$ 345.240 (1974); PA. Stat. ANn. tit. 24, $\$ 5003(1)$ (1974); UTAH CODE ANN. $\S \S 34-35-2(11), 34-35-6(f)$ (Supp. 1973). See also N.Y. Educ. LAw $\$ 313(2)$ (McKinney 1969). 
been in existence for a number of years, and the consensus of the commentators, in the absence of any definitive case raising the point, has been that the statutes are constitutional.98

Free exercise of religion. If a group could show that the exclusion of blacks was required by the group's religion, it could base a case for an exemption from $\S 1981$ on the First Amendment's ban on laws prohibiting the free exercise of religion. Many private schools organized in response to public school integration are affiliated with Protestant churches. ${ }^{99}$ At least initially these schools might present Free Exercise Clause defenses to $\$ 1981$, claiming that they are exercising a religious belief in the separation of the races or in white supremacy. ${ }^{100}$

The chance that such claims will be made does not make everything short of a blanket exemption for all private church-affiliated schools unworkable. If the court determined that the group was using religion as a subterfuge for practices based on political or social ideology, the discrimination could readily be held beyond the protection of the Free Exercise Clause. ${ }^{101}$ But even a sincere religious basis might not sustain the discrimination. Although freedom to believe is absolute, freedom to act on that belief is protected only when those acts have a substantial relationship to fundamental tenets of the religion..$^{102}$ The courts will not question the truth or desirability of the religious

The public accommodations statutes of a number of states employ general definitions which cover enterprises offering services to the public. See ALASKA STAT. $\$ 18.80 .300(7)$ (1974); Del. Code ANN. tit. 6, \$ 4501 (1974); Kan. Stat. AN. \$ 44-1002(h) (Supp. 1974); Me. Rev. Stat. ANN. tit. 5, \$4553-8 (Supp. 1973); N.M. Stat. ANn. \$ 4-33-2G (1974); Okla. Stat. ANn. tit. 25, \$1401(1) (Supp. 1974); VT. Stat. ANN. tit. 13, $\$ 1451$ (c) (Supp. 1974). These statutes might be construed to cover many private schools. See Vantine v. City of Tulsa, 518 P.2d 316 (Okla. Crim. App. 1973) (preschool which advertised to general public). A number of such statutes, however, exclude establishments which are in their nature distinctly private. See ARIz. REv. STAT. ANN. \$ 41-144I (1974); IowA CodE ANN. $\$ 601$ A.2-10 (Supp. 1974); Mo. ANN. STAT. $\$ \$ 314.020,314.040$ (Vernon Supp. 1975); Neb. Rev. STAT. $\$ \S 20-139,20-138$ (Supp. 1974); W. VA. Code ANN. \$ 5-11-3(j) (Supp. 1974); Wy. STAT. ANN. \$ 6-83.1 (Supp. 1973). See also N.J. Stat. AnN. \$ 10:5-5(l) (Supp. 1974); N.Y. ExEc. LAw $\$ 292-9$ (McKinney 1972). Very exclusive schools might escape the reach of such statutes.

98. "There is no record of a state fair educational practices act being invalidated on federal or state constitutional grounds, and it seems far-fetched to argue that the states are powcrless to forbid discrimination in education." 2 T. EMERSON, D. HABER \& N. Dorsen, Political AND Civil Rights in the UNITED States 1402 (student ed. 1967). See also Fox, Discrimination and Antidiscrimination in Massachusetts Law, 44 B.U.L. REV. 30, $70-71$ (1964).

99. Note, Segregation Academies and State Action, supra note 14, at 1447-48 \& n.68.

100. See Mlemorandum in Support of Defendants' Motion for Summary Judgment, Brown v. Dade Christian Schools, Civil No. $73-1313$ (S.D. Fla., filed Aug. 6, 1973); note 51 supra.

101. Cf. Wisconsin v. Yoder, 406 U.S. 205, 215-16 (1972) (granting the Amish sect a religious exemption from compulsory school attendance laws for children over age 14).

102. See Clark, Guidelines for the Free Exercise Clause, 83 Harv. L. Rev. 327, 361-64
(1969). 
belief itself. ${ }^{103}$ But they will independently determine from the available evidence, the importance to the exercise of the religion of the belief which forms the basis of the otherwise legally prohibited practice. ${ }^{101}$

The conclusion that school segregation is not a fundamental tenet in the religion of these groups could be based on several factors. There may be an absence of significant emphasis on school segregation or racial separation in the religious literature and programs in these churches in the past. ${ }^{105}$ The groups might also find it difficult to prove that racial separation has a fundamental importance in their religion because of past acquiescence in the interracial interaction of adults in jobs, housing, and public accommodations, and of some children in the public schools. ${ }^{106}$ The courts might conclude that many, if not most, of these schools are actually secular despite their church affiliation because their admissions are open to white students from other churches, denominations or faiths with little inquiry into religious background, and because significant religious instruction is lacking in the schools. Finally, even if the threshold showing of a religious practice of fundamental importance is sustained, such a practice must yield to a "compelling state interest," 107 and abolition of racial discrimination may be such an interest. ${ }^{108}$

Direct precedent for a right to discriminate. In the few cases where parties have asserted a right to discriminate and the courts have addressed the argument, that right has not fared well. Courts have upheld the constitutionality of state laws and regulations prohibiting

103. United States v. Ballard, 322 U.S. 78,86 (1944).

104. See, e.g., Gillette v. United States, 401 U.S. 437 (1971) (upholding the application of the draft laws to persons with a religious objection to the Vietnam war); Bratunfeld $v$. Brown, 366 U.S. 599 (1961) (upholding the application of Sunday closing laws to Orthodox Jews whose stores are closed on Saturday); Reynolds v. United States, 98 U.S. 145 (1878) (upholding the application of anti-polygamy laws to Mormons); Leary v. United States, 383 F.2d 851 (5th Cir. 1967), rev'd on other grounds, 395 U.S. 6 (1969) (upholding the application of marihuana laws to Dr. Timothy Leary despite his membership in a Hindu sect which used the drug in religious practices). See also People v. Woody, 61 Cal. 2d 716, 725 (1964) (distinguishing Reynolds and creating a religious exemption from the drug laws for an American 'Indian sect). See generally Clark, supra note 102, at 361-64.

105. Cf. Wisconsin v. Yoder, 406 U.S. 205, 235 (1972) ("history of three centuries" as a religious community).

106. In contrast, in Yoder the Court noted the pervasive separateness of the Amish community. Id. at 216. Churches affiliated with national Protestant denominations might well have to explain the existence of integrated affiliated churches in other parts of the country.

107. Sherbert v. Verner, 374 U.S. 398, 403 (1963). See, e.g., Linscott v. Millers Falls Co., 440 F.2d 14 (lst Cir.), cert. denied, 404 U.S. 872 (1971) (Seventh Day Adventist's opposition to contributing to a labor union outweighed by "the congressionally stupported principle of the union shop"); Biklen v. Board of Educ., 333 F. Supp. 902 (N.D.N.Y. 1971), aff'd, 406 U.S. 951 (1972) (personal religious opposition to loyalty oath or affirmation outweighed by state interest in "assuring the fitness and dedication of its teachers").

108. See p. 1464 infra. 
racial discrimination by labor unions ${ }^{109}$ and social fraternities at public high schools and state universities. ${ }^{110}$

The freedom of white citizens to use their governmental instrumentalities to provide for schools and other facilities which reflect their associational preferences was, of course, dramatically restricted by Brown $v$. Board of Education ${ }^{111}$ and its progeny. ${ }^{112}$ A series of cases have struck down government aid to private schools ${ }^{113}$ and clubs ${ }^{114}$ which discriminate. If the discrimination practiced by these groups was constitutionally protected, requiring the abandonment of that practice before granting government aid would run afoul of the doctrine of unconstitutional conditions. This doctrine prohibits the government from infringing on constitutional rights by requiring their

109. Railway Mail Ass'n v. Corsi, 326 U.S. 88 (1945). Justice Frankfurter, concurring, stated:

Certainly the insistence by individuals on their private prejudices as to race, color or creed, in relations like those now before us, ought not to have a higher constitutional sanction than the determination of a state to extend the area of non-discrimination beyond that which the Constitution itself exacts.

Id. at 98 .

110. See, e.g., Sigma Chi Fraternity v. Regents of the Univ. of Colo., 258 F. Supp. 515 (D. Colo. 1966). This court specifically held that "freedom of association" cases did not "uphold the right of association as applied to a social fraternity." Id. at 526. See generally Comment, supra note 83.

111. 347 U.S. 483 (1954).

112. In Green v. County School Bd., 391 U.S. 430 (1968), the Court invalidated the use of freedom-of-choice plans and held that each school board had an affirmative duty to desegregate its schools. In Swann v. Charlotte-Mecklenburg Bd. of Educ., 402 U.S. 1 (1971), the Court authorized the lower courts to employ racial quotas, busing, and radical alterations of school attendance zones to remedy past discrimination by achieving actual integration.

113. See, e.g., Norwood v. Harrison, 413 U.S. 455 (1973) (textbooks provided to private school students). See generally' Note, Segregation Academies and State Action, supra note 14 , at 1440 .

See also Green v. Connally, 330 F. Supp. 1150 (D.D.C.), aff'd sub nom. Coit v. Green, 404 U.S. 997 (1971) (denying tax exempt status to discriminatory private schools on the basis of a construction of the word "charitable" in the tax provisions). But see Bob Jones Univ. v. Simon, 416 U.S. 725, 740 n.11 (1974) (noting that this issue had not been decided by the Supreme Court in a "truly adversary controversy" and suggesting that only limited weight should be given to Coit $v$. Green). This raises doubt as to the validity of all of the tax exemption cases. See note 114 infra.

114. The states have never afforded private clubs the kind of direct aid which was extended to private schools. Recently, however, a series of Fourteenth Amendment cases have struck down indirect aid in the form of tax exemptions to private clubs which discriminate. See Falkenstein v. Department of Revenue, 350 F. Supp. 887 (D. Ore. 1972), appeal dismissed sub nom. Oregon State Elks Ass'n v. Falkenstein, 409 U.S. 1099 (1973) (state property and corporate excise tax exemptions to fraternal organizations); McGlotten v. Connally, 338 F. Supp. 448 (D.D.C. 1972) (federal income tax exemptions to fraternal orders); Pitts v. Department of Revenue, 333 F. Supp. 662 (E.D. Wis. 1971) (state property tax exemptions).

None of the decisions recognized an associational interest. The McGlotten case distinguished fraternal orders from other nonprofit social clubs on the basis of differences in the tax laws applicable to them. 338 F. Supp. at 457-59. Professor Bittker has suggested that the reasoning of the court was not sound in this regard. He argues that relying only on tax law to differentiate between groups which may discriminate and those which may not would logically lead to the application of antidiscrimination requirements to every individual and group in the country. See Bittker \& Kaufman, Taxes and Civil Rights: "Constitutionalizing" the Internal Revenue Code, 82 YALE L.J. 51, 86-87 (1972). 
waiver as a condition for the receipt of a benefit. ${ }^{15}$ Yet, few decisions have even considered the possibility of such a conflict. ${ }^{110}$ One court expressed a willingness to order the desegregation of private schools if Alabama's aid to such schools continued. ${ }^{117}$ In what is perhaps the best discussion of the issue of an unconstitutional condition, the district court in Green v. Connally'11s concluded that the right to discriminate is not as "fundamental" as freedom of speech,"119 and that even if it were, it is outweighed by "a compelling government interest in the interdiction of racial discrimination which stands on the highest constitutional ground." ${ }^{120}$ Although these cases generally arose under the Fourteenth Amendment, they have committed the judiciary to the assignment of a relatively low value to whatever right to discriminate might exist.

\section{The Limits of Legal Doctrine}

The preceding cases and discussion do not answer the question of the extent to which private groups have a right to discriminate. Instead they indicate that present law provides no unambiguous answer to this question. The law respects both individual liberty from gov-

115. This doctrine dispenses with the argument that state authority to deny a benefit entirely includes the allegedly lesser authority to grant it conditioned on the waiver of a constitutional right. As the size of the government and its largess has grown, the doctrine has been increasingly invoked. See, e.g., Perry v. Sindermann, 408 U.S. 593 (1972) (conditioning grant of tenure ta state university professor on absence of criticism of superiors infringes on freedom of speech). Shapiro v. Thompson, 394 U.S. 618 (1969) (conditioning welfare benefits on residency period infringes on right of interstate travel); Speiser $v$. Randall, 357 U.S. 513 (1958) (conditioning allowance of tax exemption on loyalty oath infringes on freedom of speech). See generally O'Neill, Unconstitutional Conditions: Welfare Benefits with Strings Attached, 54 Calif. L. Rev. 443 (1966); Van Alstyne, The Demise of the Right-Privilege Distinction in Constitutional Law, 81 HARV. L. REV. 1439 (1968); note 56 supra.

116. Courts which have mentioned defendants' arguments about rights to discriminate usually have remarked simply that there is no right to discriminate and receive government aid at the same time. See, e.g., Norwood v. Harrison, 413 U.S. 455, 462, 470 (1973); Griffin v. Board of Supervisors, 339 F.2d 486, 492-93 (4th Cir. 1964) (en banc).

117. Lee v. Macon County Bd. of Educ., 267 F. Supp. 458,478 (M.D. Ala.) (threejudge court), aff'd sub nom. Wallace v. United States, 389 U.S. 215 (1967).

118. 330 F. Supp. 1150 (D.D.C.), aff'd sub nom. Coit v. Green, 404 U.S. 997 (1971). See note 113 supra.

119. The court found it necessary to distinguish Speiser v. Randall, 357 U.S. 513 (1958), which invalidated a statute denying a tax exemption to veterans who refused to take a loyalty oath. The court relied somewhat on the chilling effect involved in Speiser which was not likely to be present in this case. $330 \mathrm{~F}$. Supp. at 1166-67. That a right to discriminate is not so important that its compulsory waiver might be deemed an unconstitutional condition was also suggested by the statement in Norwood v. Harrison, 413 U.S. 455,470 (1973), that discrimination "has never been accorded affirmative constitutional protections." See note 76 supra.

120. 330 F. Supp. at 1167 . The court in McGlotten v. Connally, 338 F. Supp. 418, 460 (D.D.C. 1972), relied on Green as authority suggesting a public policy against segregated clubs. Professor Bittker has criticized this as a shift from a rather clear policy against segregated education to a more questionable one against segregated clubs. See Bittker \&: Kaufman, supra note 114, at $76-77$. 
ernment intrusion and racial equality through the operation of law. The choice between these two values has already been made in the contexts of the home on the one hand, and public, commercial business on the other. Private clubs and schools possess a unique mix of the characteristics of these two institutions. In this middle ground, the legal system as yet has neither made the necessary choice nor committed itself. A court called on to make this decision, therefore, can exercise a relatively wide degree of discretion. ${ }^{121}$ In these circumstances, making the decision will amount to an act of policymaking.

\section{A Right to Discriminate: The Policy Considerations .}

The process of creating a policy defining permissible racial discrimination by individuals in groups requires a weighing of strong opposing interests. The process of assigning values to important competing interests and attempting to strike an optimal balance between them depends ultimately upon the subjective value judgments of the decisionmakers. But before assigning values and balancing, an effort must be made to identify the conflicting interests and to predict the effects that alternative resolutions will have on those interests. Because of the high costs of preserving private club and school discrimination in the face of $\S 1981$ 's broad sweep, the optimal protection to be afforded these competing interests might be something less than the blanket exclusions which were unquestioned before 1968. The following analysis will examine the competing interests and suggest ways of limiting the impact of $\S 1981$ short of a blanket exemption.

\section{A. The Costs of Protecting Private Discrimination}

\section{The Perpetuation of "Badges and Incidents of Slavery"}

The grant of congressional authority under the Thirteenth Amendment to eliminate badges and vestiges of slavery was based on the proposition that the freed men could not achieve full free citizenship if they had to make their way in a society cluttered with monuments to their former condition of servitude. ${ }^{122}$ The badge of slavery iden-

121. The recent decision in McCrary v. Runyon, No. 73.2348 (4th Cir., Apr. 15, 1975) is illustrative. The four-judge majority, concluding that $\$ 1981$ should reach explicit racial discrimination, distinguished past cases on freedom of association, right of privacy and parental rights in a manner similar to that described above. See notes $81,87,95$ supra. The three-judge dissent, concluding that $\$ 1981$ should not reach private schools, emphasized the dicta in past Supreme Court cases. See notes 76, 77 supra.

122. See Jones v. Alfred H. Mayer Co., 392 U.S. 409, 437-44 (1968). 
tified in Jones was racial discrimination-practices based on the assertion that significant variations in the qualities of human beings can be predicted by race alone. Today the concept of inherent racial inequality survives in the bylaws ${ }^{123}$ and admissions policies ${ }^{124}$ of private clubs and schools which can reject the black applicant with no more justification than "no blacks allowed." The use of racial classifications is psychologically harmful to minority group members. ${ }^{125}$ These "badges of slavery" are also signals to other members of the white majority that racial prejudice has not yet become too discredited to express openly. The Civil Rights Act of 1866 presents an opportunity to eliminate some of these remaining vestiges of slavery which would be lost by a court decision broadly protecting private discrimination.

\section{Judicial Validation of Racism}

In numerous cases over a period of many years the Supreme Court has emphatically established the proposition that classifications based on race are irrational and wrongful. ${ }^{26}$ In Brown v. Board of Educa$t_{i o n}{ }^{127}$ the Court found that government approval of such classifications compounds the harm they cause to minority group members. A court attempting to define an exemption from $\$ 1981$ could not effectively maintain neutrality regarding the racial discrimination. Despite disclaimers in the opinion, a decision legitimating the discrimination practiced by these groups would present the appearance of government approval of the theory of race inequality.

123. For example, the National Constitution of the Benevolent and Paternal Order of Elks, art. VI, $\$ 4$, provides that in order to be considered for membership an applicant must be "a white male citizen of the United States, of sound mind and body, of good character, not under the age of 21 years, and a believer in God." N.Y. Times, Aug. 13, 1972, § 6 (Magazine), at 9.

124. In Gonzales v. Fairfax-Brewster School, Inc., 363 F. Supp. 1200, 1202-03 (E.D. Va. 1973), for example, the record contained evidence of several instances in which persons inquiring by phone were told that no blacks were allowed in the school.

125. The use of racial classifications tends to convince many minority group members that they actually are inferior. This in turn robs them of the ambition necessary for advancement. See generally G. Simpson \& J. Yincer, Racial and Cultural Minorities 147-50 ( $3 \mathrm{~d}$ ed. 1965). This conclusion, supported by authoritics in psychology and sociology in the now-famous footnote 11, led the Supreme Court to hold that separate schools were inherently incapable of providing equal educational opportunity. Brown v. Board of Educ., 347 U.S. 483, 494 \& n.11 (1954).

Although the focus has been elsewhere, it should not be overlooked that the use of racial classifications can be psychologically harmful to majority group members as well. See G. SIMPSON \& J. YINGER, supra at 182-87.

126. See, e.g., Hirabayashi v. United States, 320 U.S. 81, 100 (1943); Yick Wo v. Hopkins, 118 U.S. 356,374 (1885).

127. 347 U.S. 483,494 (1954). 


\section{The Denial of Equal Opportunity to Black Citizens}

Educational opportunity. As desegregation proceeded under court in the South, ${ }^{128}$ over half a million students fled the public schools and entered white-only private schools. ${ }^{129}$ These segregation academies undermine the nation's policy of providing integrated educational opportunity. ${ }^{130}$ In many school districts little actual school integration exists because so ferw whites remain in the public school system. ${ }^{131}$ The result is the perpetuation of dual school systems, ${ }^{132}$ just as separate and perhaps as inherently unequal as those dismantled after Brown. The psychological harm to young black students may not be much less merely because the white schools do not receive affirmative aid from the states.

The rise of the segregation academy also threatens educational opportunity for blacks by undermining the public schools. The massive exodus of students from the public schools in some areas has caused the loss of state aid, local financial support, and experienced faculty and staff. ${ }^{133}$ This deterioration of the public school system, coupled with more drastic measures to achieve racial balance using the few white students remaining, ${ }^{134}$ has often further accelerated the exodus of white students from the system. Rarely have the remaining blacks had such an alternative.

The application of $\$ 1981$ to private segregation academies would eliminate their primary reason for existence, the right to discriminate in the admission of students. While actual integration of these schools might not be achieved immediately, $\S 1981$ would be a useful tool for civil rights groups seeking to restore public support for the public school systems.

Access to private social clubs. Unlike segregation academies, whiteonly private social clubs have been a part of American society for years. ${ }^{135}$ Membership in some clubs can be an important source of

128. The flight to private schools has also occurred in northern cities where desegregation plans have had great impact. See Wall St. J., Apr. 7, 1975, at 1, col. 1 (Boston).

129. The estimated enrollment in private schools organized or cxpanded as a result of public school desegregation grew from roughly 25,000 in 1966 to approximately 535,000 in 1972. Note, Segregation Academies and State Action, supra note 14, at 1441 \& $n .44$ $(1973)$.

130. That a policy favoring actual integration of the schools exists is evident from the recent decisions abandoning "color-blindness" in favor of devices to achieve racial balance in the schools. See note 112 supra.

131. Note, Segregation Academies and Stale Action, supra note 14, at 1451-52 \& nn. $82-83$.

132. Id. at 1453 .

133. Id. at $1452-53$ \& $\mathrm{nn} .86-90$.

134. Id. at 1452 \& $\mathrm{n} .85$.

135. These clubs take the form of thousands of country clubs, city clubs, athletic clubs and fratcinal orders. See generally Note, supra note 80, at 1186-90. 
business opportunity. Country clubs and downtown clubs are often the setting for new business contacts and business entertaining. There is evidence that executive job promotion is often dependent on club membership. ${ }^{136}$ In some areas clubs may hold a local monopoly on a particular type of recreational facility or dining establishment. The continuance of blanket racial exclusion would deny these advantages to blacks, regardless of how well they might meet other nonracial admissions criteria.

\section{The Lost Potential for Social Integration}

Private schools and private clubs are often indistinguishable in their operations and ambience from public schools, restaurants, bars, and pools open to the general public. By instituting a system of selectivity and paying membership fees or tuition, whites can escape the racial integration mandated by court decisions and legislation. To the extent that there is a national policy of promoting integration for its own sake, this policy is undermined by the maintenance of a system in which whites can, in effect, purchase the right to maintain segregation. The capacity of $\S 1981$ to bring about integration is rather limited, however, when compared to the judicial application of the Fourteenth Amendment for the desegregation of public schools. Section 1981 gives the black citizen the "same right" as white citizens have, but the option of exercising that right remains his. Even if $\S 1981$ were applied without qualification to every institution currently barring access to blacks, the white custodians of those institutions would still possess the full complement of informal social sanctions which could make entry distasteful to blacks.

In many large clubs and private schools, however, the significance of being unwanted by some of the members may be relatively unimportant compared to the benefits of gaining access described above. Section 1981 can promote actual integration by invalidating restrictive convenants and bylaws in organizations in which most existing members of the group are too indifferent to repeal them voluntarily.

This would allow nonprejudiced group members to invite blacks to associate with them. Furthermore, local groups could eliminate racial

136. Id. at 1188, 1216-17: See also Brief for 13'nai Brith as Anicus Curiac at 23-28, Moose Lodge No. 107 v. Irvis; 407 U.S. 163 (1972); S. Mysliwiec, Regulating Discriminatory Practices of Private Organizations in Pennsylvania, Jan. 1974 (unpublished Yale Legislative Services report). 
restrictions without the threat of sanctions from affiliated groups elsewhere. ${ }^{137}$

\section{B. The Costs of Restricting Group Freedom to Exclude Blacks}

\section{Forced Interracial Social Intercourse}

The argument against government intervention is based on the notions that individual freedom includes the rights to join voluntarily with others for any benign purpose, to establish by mutual consent reasonable rules for governing group activity, ${ }^{138}$ to extend invitations to others to join as a matter of unfettered discretion, ${ }^{139}$ and to leave the group or disband it at will.140 Since these "rights" describe actual behavior that may well predate what are now known as governments, they are arguably among the "natural" rights which, according to the Ninth Amendment, the people have not surrendered to their government. ${ }^{141}$

Section 1981 would not completely eliminate discretion in the admission of new persons to the groups. It would merely prohibit the use of race to deny admission to blacks. The specific interest threatened is the desire of groups and their members to prevent interracial social contact. ${ }^{142}$ Groups with racial barriers think that they would

137. See Junior Chamber of Commerce v. Missouri State Jr. Chamber of Commerce, 508 F.2d 1031 (8th Cir. 1975) (suit for preliminary injunction to enjoin the United States Jaycees from revoking the charter of the Kansas City Jaycees and removing a convention from Kansas City to another site, alleging that such actions in response to local chapter's admission of women in violation of national bylaws would violate the Fourteenth Amendment; injunction denied for lack of state action). Cf. Washington Branch of Am. Ass'n of Univ. Women v. American Ass'n of Univ. Women, 79 F. Supp. 88 (D.D.C. 1948), aff'd, 175 F.2d 368 (D.C. Cir. 1949) (branch affiliate may admit blacks due to lack of restriction in national constitution or bylaws).

138. See, e.g., Cox v. Government Employees Ins. Co., 126 F.2d 254, 256 (6th Cir. 1942).

139. See, e.g., Burrell v. Michaux, 286 S.W. 176, 181 (Tex. Comm'n App. 1926), aff'g 273 S.W. 874 (Civ. App.), rev'd on other grounds sub nom. Ancient Egyptian Arabic Order of Nobles v. Michaux, 279 U.S. 737 (1929) (segregation of races by limiting membership to white men may be enforced by a court of equity).

140. See, e.g., NLRB v. Local 1029, Textile Workers Union of America, 409 U.S. 213, 216 (1972).

141. U.S. Const. amend. IX:

The enumeration in the Constitution, of certain rights, shall not be construed to deny or disparage others retained by the people.

See generally Griswold v. Connecticut, 381 U.S. 479, 486-99 (1965) (Goldberg, J., concurring); Henkin, supra note 85, at 1412-16; Redlich, Are There "Certain Rights... Retained by the People"?, 37 N.Y.U.L. REv. 787, 802-12 (1962). But see Pollak, Thomas I. Emerson, Lawyer and Scholar: Ipse Custodiet Custodes, 84 YALE L.J. 638, 643-47 (1975).

142. Private groups may also feel that any government control over admissions criteria will lead to the ultimate invalidation of other, nonracial criteria and a substantial lessening of their freedom to choose social intimates. Given the history of the Thirteenth Amendment and $\$ 1981$, however, government intrusion could be explicitly limited to forbidding the use of race as a criterion. But see note 40 supra. 
find it unpleasant to have to talk to blacks, to see them, to be in close physical proximity to them, or to have them participate in group activity. The individual who finds interracial contact unpleasant may now find it unavoidable in a variety of contexts of daily life. But the special nature of private groups such as social clubs and schools may make the infringement of the segregation interests more harmful in those contexts. The right of a person to select others to invite into his home on a completely arbitrary basis might be considered a basic element of liberty. ${ }^{143}$ It may be desirable to extend this sort of sanctuary from government supervision beyond the home to groups like clubs and schools.

\section{Impairment of Parental Control over the Education of their Children}

The application of $\$ 1981$ in the private school context would infringe upon the special interest of parents in providing a segregated educational environment for their children. These parental desires may stem from several sources. Parents may feel that segregated schools contribute to the indoctrination of children with racial prejudice. In addition, parents may think that black children are inherently less capable of contributing to the academic atmosphere of the classroom than white children. Fear of social contact within the school leading to interracial dating and marriage may be a considerable motivating factor for parents.

The desegregation of public schools, of course, substantially impaired parental access to segregated schools. The specific privilege threatened by $\$ 1981$, then, is the ability of parents who are willing and able to pay both school-supporting taxes and private school tuition to provide a segregated school for their children. The case for preserving this system does not draw support from these parental attitudes, but rather from the proposition that parents should have the opportunity to substitute their own judgment for that of the government regarding the education of their children.

\section{Alternative Policies Toward Private Group Discrimination}

In applying $\S 1981$ to private groups, the choice presented to the courts is not as simple as merely granting or denying an exemption. Alternatives are available with corresponding degrees of infringement

143. See note 74 supra. 
on private group freedom to discriminate. Because the costs of protecting private discrimination may be substantial, a careful consideration of the alternatives may lead a court interested in preserving some degree of private group autonomy to choose something less than a blanket exemption from $\$ 1981$.

\section{A. Defining an Exemption from $\S 1981$ \\ 1. Exempting All Bona Fide Private Groups}

This solution would reestablish the conditions that obtained before the revitalization of $\$ 1981$ in Jones. Groups "not in fact open to the public" would have the right to discriminate under federal law. A court could hold $\S 1981$ inapplicable to these groups on the grounds that they had a superior constitutional right to discriminate. However, because constitutional validation of discrimination might not be desirable, the constitutional issue might be avoided by ruling that the private club exemption in the 1964 legislation worked an implied repeal of the 1866 Act. This solution would incur all the costs of protecting private discrimination described above.

\section{Exempting Only Private Groups in Which Extraordinary Associational Interests Are Threatened}

Some commentators have suggested that a constitutional right to discriminate could be based on a showing that discrimination is necessary to preserve the purpose and nature of the particular group. ${ }^{144}$ The factual characteristics which would satisfy this test would be developed from the experience in several cases. The courts could look to the purpose of the group to determine whether the members have joined together primarily for fellowship with each other or primarily to share the use of a facility, as in some recreational clubs, or to obtain a service, as in some schools. The court could also hear evidence on the nature of the activity within the group. The court would look to the size of the group, whether the members all know each other, and whether they regularly meet together or instead use club facilities independently and randomly.

144. See, e.g., Note, supra note 80, at 1214-17; Note, Association, Privacy and Private Clubs: The Constitutional Conflict, supra note 3, at 469-70; Note, Developing Legal I'istas for the Discouragement of Private Club Discrimination, 58 IowA L. Rev. 108, 13641 (1972). The dissent in McCrary v. Runyon, No. 73-2348 (4th Cir., Apr. 15, 1975), slip opinion at 36-37, emphasized the small size of the schools and hinted that larger schools might not have a right to discriminate. 
This approach would improve the potential for access by blacks to some groups and facilitate some integration. But the protection afforded explicit racial exclusion by other groups would preserve "badges of slavery" and lend judicial approval to them. For these reasons the alternatives which follow may be more desirable.

\section{B. Applying $\$ 1981$ to Private Groups Subject to Interpretative Limitations}

1. Prohibiting the Use of Race by Groups Employing Objective Admissions Criteria

This solution relies on a distinction between two types of private groups. ${ }^{145}$ The first type consists of groups which exercise selectivity by excluding categories of persons. They may restrict entry on the basis of criteria such as education, income, political affiliation or professional status. The members of the group do not attempt to judge the individual personal characteristics of applicants who fit into acceptable categories. This type of group includes many large clubs and most private schools. To a person who belongs to the appropriate categories this type of institution resembles a public accommodation; if he seeks admission he will be admitted and served. Allowing such a group to use race as a criterion means that blacks who could meet every other qualification will be barred. The second type of group is the one in which the existing members, either directly or by committee, interview prospective applicants and decide on extending membership on the basis of subjective and usually unstated criteria. These groups have preserved the ability to reject an applicant because he "would not fit in" or because members "do not like him." Even a white applicant in many ways similar to the existing members will not be admitted if a number of existing members could be expected not to "like" him.

The "same right" guaranteed by $\$ 1981$ would require that the first type of group formally consider a black applicant and admit him if he meets nonracial admissions criteria. ${ }^{146}$ Such a rule might contribute

145. One commentator has asserted that this is the correct interpretation of $\$ 1981$. See Note, Federal Power to Regulate Private Discrimination: The Revival of the Enforcement Clauses of the Reconstruction Era Amendments, supra note 3, at 494-95. The position presented here is that it is better viewed as one of several policy alternatives.

146. McCrary v. Runyon, No. 73-2348 (4th Cir., Apr. 15, 1975). This policy rejects the proposition underlying the exemptions from $\$ 1981$ that by rejecting some whites a group gains the right to reject all blacks. The McCrary court may have found the rejection of that notion so sensible that it failed to realize that it was making new law. See note 54 supra. 
substantially to the rights of blacks without unduly harming private groups. Some old group members might not like having new black members around. But the nature of the selection process in the past never insured the exclusion of new white members with whom some members would rather not associate. Because the nature of the group was such that there was no prerequisite that everyone "like" (or in some instances even know) everyone else, the disruption of the group caused by the admission of blacks might not be very great. Black members might be able to use club facilities and associate with members who do accept them with relatively little forced contact with those who do not. ${ }^{147}$

A strict construction of $\S 1981$ would not, however, guarantee a black applicant admission to the second type of group. The statute entitles him to the "same right" as white persons; such a right would not include actual admission because no white person has guaranteed admission to these highly selective groups. Such groups could reject black applicants after formal consideration because they "do not like" them. Of course, a court could attempt to determine the real reason for the rejection of a black applicant by such a group. But a court adopting this limited application of $\$ 1981$ would refrain from doing so on the basis of a conclusion that in such groups generally interpersonal contact is very important, and the disruption caused by forced integration could outweigh the benefits. This policy conclusion would not require an exemption from $\S 198 \mathrm{I}$; a court could merely refer to the right of private groups to be arbitrary and profess an inability to conclude from available evidence that the refusal was based solely on race. ${ }^{148}$

The major benefit of this approach would be the elimination of "badges and incidents of slavery," rather than actual integration. Clubs and schools would have to abandon racist bylaws and admissions policies and the practice of summarily rejecting black applicants. Actual integration would be limited by the fact that groups could shift their admissions policies and continue to exclude blacks for "subjective"

147. Of course, the prejudiced member would be able easily to identify these new members to whom he objects because of their racial characteristics. But the trauma caused by his merely having to see them may be little more than he experiences constantly in the general community. Part of the philosophy behind integration has been that such attitudes are based on ignorance and will diminish as an individual's experience of interracial contact increases. See G. SMmpon \& J. Yinger, supra note 125, at 503, 510.

148. This may be what the court did in Riley v. Adirondack S. School for Girls, 368 F. Supp. 392 (M.D. Fla. 1973). See note 44 supra. The court said that "the evidence [was] insufficient to warrant a finding that, but for race, the minor Plaintiff would have been admitted to the school." Id, at 398 . But see note 153 infra. 
reasons. ${ }^{140}$ Despite this loophole, horvever, some integration might result from the elimination of explicit exclusionary policies where members are otherwise too indifferent to evade the statute actively.150

\section{Freezing Past Admissions Criteria}

This approach would be the same as the one above, but would also deny groups which had used only objective admissions criteria the right to shift to subjective criteria and continue to exclude blacks. Groups which were not so intimate that they required subjective screening of applicants in the past arguably do not have a legitimate need for such procedures merely because explicit racial exclusion has been eliminated. The shift in procedure could be enjoined as an attempt at evasion of $\S 1981$. That statute could be held to guarantee the "same right" in substance as well as form. ${ }^{151}$

This approach would result both in greater access to private schools and clubs for blacks and in more integration, at the expense of whites who would rather avoid interracial social contact. In estimating the extent to which such groups will be disrupted by a broad application of $\S 1981$, however, due regard should be paid to the likelihood that the problem will have a self-adjusting aspect. Intimate social groups in which the prejudice against blacks is most widely shared and intensely felt will be those which blacks will be the most reluctant to attempt to penetrate. Where the potential for interpersonal conflict is lower because the group is larger or feelings are less militant, blacks will be more likely to make use of $\S 1981$.

149. Integration would also be limited by the fact that disproportionate numbers of blacks might not be able to mect some objective nonracial admissions criteria. These objective criteria might be attacked on the basis of similar successful challenges in the employment area under Title VII and $\$ 1981$. See, e.g., Griggs v. Duke Power Co., 401 U.S. 424 (1971). But in the social group realm, the very purpose of admissions criteria is to reflect preferences of the group generally held to be legitimate. A showing that the criterion also actually serves to exclude whites who are not wanted should be a sufficient justification if the generally accepted notion of freedom to associate is to be preserved. One of the first private club cases to confront this issue is Olzman v. Lake Hills Swim Club, Inc., 495 F.2d 1333 (2d Cir. 1974).

The problem which this Note primarily addresses is discrimination against blacks who could meet the nonracial criteria which current and future white members qualify under. After eliminating overt discrimination, the chief obstacle to the elimination of this practice is the improper use of "subjective" criteria.

150. See pp. 1468-69 supra.

151. This approach could be analogized to the remedy used by the courts in the voting rights cases in the early 1960 's. See, e.g., United States v. Duke, 332 F.2d 759 , 768.69 (5th Cir. 1964) (to remedy past discrimination in voter registration county required to freeze actual standards under which the white voters had been registered and allow blacks to qualify under those standards for at least a year). See generally Fiss, Gaston County v. United States: Fruition of the Freezing Principle, 1969 Sur. CT. REv. 379 (1969). 


\section{Requiring That Groups Justify the Use of Subjective Screening Procedures Which Have the Effect of Excluding Blacks}

This approach would require all groups whose subjective admissions procedures have the effect of excluding blacks to show that the procedure is necessary to preserve the purpose and nature of the group. This requirement would be imposed regardless of the procedures used in the past. The court would look to characteristics of the group such as those described above in the discussion of a limited right to discriminate openly. ${ }^{152}$ But the test would be whether the group requires the use of subjective admissions criteria; no group would be permitted to justify an exclusion on the basis of race itself. ${ }^{153}$

The legal basis of this approach would be that the unnecessary use of subjective criteria is an indirect method of denying blacks the "same right" guaranteed by $\$ 1981$. Support could be drawn from the Supreme Court's decisions in the area of employment discrimination. In Griggs v. Duke Power Co. ${ }^{154}$ the Court established the rule that required job qualifications and examinations which exclude disproportionate numbers of black applicants violate the employment discrimination statutes unless the requirements serve "business necessity." The test here might be thought of as requiring a showing of "social necessity" before a group is allowed to exercise arbitrary personal preference in the selection of new members to the detriment of blacks.

\section{Judicial Review of Admission Decisions}

The most extreme and interventionist alternative could be for the court to attempt to second-guess the group's reasons for excluding an applicant. A group might be required to show rational reasons other than race or arbitrary preference for excluding a black applicant. This alternative would come closest to eliminating the ability of groups to exercise personal preference in judging the nonracial characteristics of

152. Sce p. 1471 supra.

153. Thus, while a requirement of approval by two-thirds of the membership might be acceptable for a small bridge club, it might serve no purpose independent of racial exclusion when used by a large golf or tennis club. Because the social aspects of a school of any size are relatively minor when compared to the educational functions, a court might hold as a matter of law that the screening of new students on the basis of the personal preferences of the student body, or a committee of students or administrators is impermissible where racial exclusion is the result. In Riley v. Adirondack $S$. School for Girls, 368 F. Supp. 392 (M.D. Fla. 1973), the court drew heavily on identifiable, rational and essentially objective reasons for excluding the plaintiff: age, maturity, and parental attitude. The court might well have hesitated to dismiss the case if the only reason the headmaster could provicle was that he or other students did not "like" the plaintiff.

I54. 401 U.S. 424 (1971). 
an applicant. ${ }^{155}$ For this reason, it seems to go beyond giving a black applicant the "same right" a white applicant currently has.

\section{Conclusion}

The judicial resurrection of the 1866 Civil Rights Act by the Supreme Court in 1968 amounted to the equivalent of new legislation enacting a broad, general purpose statute prohibiting discrimination against blacks. In the employment discrimination area it has come to be a useful supplement to other statutes without creating significant problems. But as $\S 1981$ is increasingly applied to discrimination by private groups, the question of the extent to which groups have a right to freedom from government supervision necessarily arises. Legal doctrines developed in the past have recognized the interests involved, but have done little to answer the question posed where those interests come into direct conflict.

In resolving the conflict between private groups and individual equality, the courts should recognize the existence of several alternative solutions for reconciling the opposing interests. The courts can maintain a meaningful freedom for private groups to choose social intimates without granting a blanket and absolute right to practice racial discrimination. Because of the high costs of racial discrimination, limitations on the great potential offered by $\$ 1981$ should be adopted only after the most careful consideration. The purpose of this Note has been to contribute to that deliberation.

155. See note 139 supra. 